\title{
Anna Barańska
}

https://orcid.org/0000-0002-8509-7520

Instytut Historii Katolickiego Uniwersytetu Lubelskiego Jana Pawła II

\section{Projekt konstytucji rosyjskiej z 1820 roku - tryumf czy zapowiedź końca Królestwa Polskiego?}

Zarys treści: Przedmiotem artykułu jest analiza projektu konstytucji rosyjskiej z $1820 \mathrm{r}$. w kontekście polityki wewnętrznej i polityki polskiej Aleksandra I. Utworzenie Królestwa Polskiego dało carowi możliwość przetestowania systemu, który zamierzał wprowadzić w całym Cesarstwie. Miał on polegać na połączeniu ustroju konstytucyjnego z autokratyczną władzą monarchy.

Outline of content: The article is an analysis of a draft Russian constitution of 1820 in the context of internal policy and policy toward Poland conducted by Tsar Alexander I. The creation of the Kingdom of Poland allowed the tsar to test the system he wanted to impose on his whole Empire. It was to combine the constitutional political system with his autocratic power.

Słowa kluczowe: projekt konstytucji rosyjskiej z 1820, Aleksander I, Królestwo Polskie 1815-1830

Keywords: draft of the Russian constitution of 1820, Alexander I, Kingdom of Poland 1815-1830

W „Manifeście o powstaniu narodu polskiego” z 20 grudnia 1830 r. senatorowie i posłowie, nawiązując do upadku Księstwa Warszawskiego i utworzenia Królestwa Polskiego w 1815 r., oświadczali: „Słodziliśmy [...] pierwsze chwile wydartej nam na nowo niepodległości tą myślą, że połączenie pod jednym berłem, jakkolwiek dla nas szkodliwe, przyniesie czterdziestomilionowemu ludowi uczestnictwo swobód konstytucyjnych, które w całym ucywilizowanym świecie stały się równie potrzebą panujących, jak rządzonych"1.

We wstępie do pierwszego wydania rękopisu konstytucji Cesarstwa Rosyjskiego, znalezionego przez powstańców w kancelarii Nikołaja Nowosilcowa, minister spraw zagranicznych Andrzej Horodyski deklarował:

${ }^{1}$ Diariusz Sejmu z r. 1830-1831, wyd. M. Rostworowski, t. 1, Kraków 1907, s. 63. 
Rząd Narodowy [...] prawdziwej doznał radości z odkrycia śladów, że była kiedyś dla Rosjan szczęśliwa chwila, w której głos prawdy przedarł się do podwojów samodzierżcy i żądał ustawy zasadniczej; że i w Rosji nareszcie tak ważnym, a pewnie najpożądańszym dla mieszkańców tego kraju zaczęto się zajmować dziełem. [...] Projekt ustawy rosyjskiej przyswoił z niej [Konstytucji Królestwa Polskiego] wiele artykułów, jak o tym wzmianki na boku rękopismu znajdujące się świadczą ${ }^{2}$.

Blisko sto lat później emigracyjny historyk rosyjski Gieorgij Władimirowicz Wiernadski (1888-1973) napisał: „Ironią losu było to, że konstytucję, której ostrze zostało wymierzone przeciw polskim roszczeniom, opublikował złośliwie polski rząd rewolucyjny podczas powstania 1831 roku"3.

Czym była „Ustawnaja Gramota” - projekt konstytucji Cesarstwa Rosyjskiego z 1820 r. i jakie miała związki z konstytucją Królestwa Polskiego oraz z polityką polską cara Aleksandra I? ${ }^{4}$

\section{Reformatorskie i konstytucyjne plany Aleksandra I}

Projekt rosyjskiej ustawy zasadniczej z 1820 r. nie był izolowaną inicjatywą. Poprzedził go cały szereg reformatorskich planów opracowywanych pod auspicjami Aleksandra I od początku jego panowania ${ }^{5}$. Część z nich dotyczyła Cesarstwa Rosyjskiego, inne - terytoriów nowo anektowanych, niektóre wiązały się z ideą przebudowy politycznej Europy.

Sprawa reform wewnątrzrosyjskich omawiana była najpierw na forum Komitetu Niejawnego (od czerwca 1801 do końca 1803 r.), w którym zasiadali „młodzi przyjaciele" cara: Adam Jerzy Czartoryski, Wiktor Koczubej, Nikołaj Nowosilcow i Paweł Stroganow. Główny przedmiot dyskusji stanowiły reformy systemu administracji w Cesarstwie i zapewnienie poddanym opieki prawa. W 1802 r. Aleksander zreorganizował centralne organy władzy państwowej, likwidując działające od czasów

2 Odpis wstępu A. Horodyskiego z 30 VII 1831, Biblioteka Jagiellońska (dalej: BJ), rkps 6980 I, k. 3r, 4r, 5r.

${ }^{3}$ G. Vernadsky, La Charte constitutionnelle de l'Empire russe de l'an 1820, trad. du russe par S. Oldenburg, Paris 1933 (wyd. ros. ukazało się w Pradze w 1925 r.).

${ }^{4} \mathrm{~W}$ zakończeniu studium o polskiej polityce Aleksandra I wyraziłam opinię, że dalsze badania nad tym problemem powinny zmierzać do usytuowania go „we właściwym kontekście, jako jednego z elementów szerszej strategii Aleksandra, zarówno w sprawach wewnętrznych Cesarstwa Rosyjskiego, jak i na arenie międzynarodowej”, A. Barańska, Polityka polska Aleksandra I, w: Wolnomularstwo Narodowe. Walerian Łukasiński, red. W. Śliwowska, Warszawa 2014 (Polskie ruchy społeczno-polityczne i życie literackie 1815-1855. Studia i materiały), s. 72. Inspiracją do powstania prezentowanego tu artykułu był pierwszy z tych postulatów.

${ }^{5}$ Charakterystykę reform związanych z panowaniem Aleksandra I można znaleźć we wszystkich opracowaniach syntetycznych dotyczących historii Rosji (w jęz. polskim przede wszystkim L. Bazylow, Historia Rosji, Wrocław 2006 lub wcześniejsze wydania). Szczegółowe omówienie zob. Л.Ф. Писарькова, Государственное управление России в первой четверти ХІХ века. Замыслы, проекты, воплощение, Москва 2014. 
Piotra I kolegia i wprowadzając na ich miejsce osiem ministerstw (w tym nieistniejący wcześniej resort oświaty). Zmodernizowany został system szkolnictwa. W Cesarstwie powstało sześć okręgów naukowych, których centra stanowiły stare lub nowo otwarte uniwersytety ${ }^{6}$. W 1804 r. Aleksander zlecił sekretarzowi Komisji Kodyfikacyjnej Gustawowi Rozenkampfowi ${ }^{7}$ przygotowanie projektu konstytucji dla Rosji. Prace te przerwała wojna z napoleońską Francją. W latach 1808-1812 zadanie opracowania kompleksowego planu reform wewnętrznych przeszło w ręce nowego doradcy i współpracownika cara, Michaiła Sperańskiego. Główne założenia projektu Sperańskiego zostały przedstawione we „Wstępie do zbioru ustaw państwowych" z 1809 r. Przewidywał on utworzenie czterostopniowego systemu organów reprezentacyjnych i sądowych, powołanie Rady Państwa koordynującej władze ustawodawcze, usprawnienie i centralizację władzy wykonawczej w terenie oraz nowy podział administracyjny Cesarstwa (z dużą liczbą niewielkich guberni w centrum i pięcioma dużymi obwodami na peryferiach). Późniejsze (z 1811 r.) propozycje zakładały podział Senatu na dwa departamenty: administracyjny (Komitet Ministrów pod przewodnictwem cara) i sądowniczy (Najwyższy Trybunał) oraz utworzenie odrębnych senatów w Petersburgu, Moskwie, Kijowie i Kazaniu ${ }^{8}$.

W 1812 r. Sperański znalazł się w niełasce i został zesłany do Permu, a inwazja francuska i dwuletnia kampania wojenna odwróciły uwagę Aleksandra od problemu reform ustrojowych. Jednak zaraz po kongresie wiedeńskim powrócił on do swoich zamierzeń, $\mathrm{w}$ związku $\mathrm{z}$ czym zaczęły powstawać kolejne plany. W 1816 r. Nowosilcow opracował projekt podziału Cesarstwa na namiestnictwa kierowane przez obdarzonych szerokimi kompetencjami namiestników - bezpośrednich reprezentantów monarchy9. W prowincjach nadbałtyckich zostało zniesione

${ }^{6}$ W 1802 r. zaczął działać uniwersytet w Dorpacie, w 1803 - w Wilnie (jako uczelnia polska kontynuacja Szkoły Głównej Litewskiej), w 1804 - w Kazaniu, w 1805 - w Charkowie. Plany utworzenia dwóch kolejnych okręgów z uniwersytetami w Tobolsku i Uściługu nie doszły do skutku. Zob. L. Bazylow, op. cit., s. 254; A. Krusenstern, Rys systemu, postępów i stanu oświecenia publicznego $w$ Rossyi, tłum. K. Jerzmanowski, Warszawa 1838, s. 26.

7 Gustav Adolf von Rosenkampf (1764-1832), pochodził ze szwedzkiej rodziny osiadłej na Łotwie, studiował w Lipsku, za panowania Katarzyny II był przez kilka lat urzędnikiem Kolegium Spraw Zagranicznych; w 1803 r. Aleksander I powołał go do Komisji Kodyfikacyjnej. Zob. П.М. Майков, Розенкампф Густав Андреевич, w: Русский биоргафический словарь, ред. А.А. Половцов, т. 16, Санкт-Петербург 1913, с. 365-371. Komisja Kodyfikacyjna została wcześniej podporządkowana Ministerstwu Sprawiedliwości, którym kierował Piotr Wasiliewicz Łopuchin, a funkcję towarzysza ministra sprawował Nikołaj Nowosilcow.

8 J.P. LeDonne, Regionalism and constitutional reform 1819-1826, „Cahiers du monde russe” 44 (2003), no. 1, s. 16-17. Szczegółową bibliografię dotyczącą osoby i działalności Sperańskiego podaje Д.Н. Шилов, Государственные деятели Российской империи. Главы высших иентральных учреждений 1802-1917. Биобиблиограбический справочник, Санкт-Петербург 2002, с. 675-681. John P. LeDonne (ur. 1935), historyk amerykański, związany obecnie z Ukrainian Research Institute i Davis Center for Russian Studies na Harvard University.

9 С.В. Мироненко, Самодержавие и ребормьл. Политическая борьба в России в начале ХІХ века, Москва 1989, с. 178-179. Projekt ten był szeroko dyskutowany w wyższych kręgach 
poddaństwo osobiste chłopów (1816-1819). W 1818 r. powstał plan likwidacji poddaństwa w całej Rosji drogą wykupu chłopów przez państwo, autorstwa gen. Aleksieja Arakczejewa; wkrótce tym samym problemem zajęła się komisja pod przewodnictwem ministra finansów Dymitra Guriewa ${ }^{10}$. Wszystkie wymienione projekty (od 1801 r.) łączyło to, że nawet jeśli uzyskały aprobatę cara, to albo nie doczekały się realizacji, albo zostały wprowadzone w życie tylko częściowo bądź $\mathrm{w}$ zmienionej formie.

Bardziej konsekwentna wydawała się liberalna polityka Aleksandra I wobec nowych prowincji, które Rosja pozyskała w okresie wojen napoleońskich. Przyłączał je do Imperium jako kraje autonomiczne, z zachowaniem odrębności ustrojowo-prawnej. Zdobyta w 1809 r. na mocy porozumienia ze Szwecją Finlandia otrzymała status wielkiego księstwa, $\mathrm{z}$ gwarancją poszanowania "praw konstytucyjnych” i szeroką autonomią wewnętrzną. Co więcej, Aleksander w $1811 \mathrm{r}$. scalił z nią prowincję wyborgską (tzw. starą Finlandię), należącą do Rosji od 1721 r. Ziemie Księstwa Warszawskiego zostały w 1815 r. połączone z Cesarstwem jako autonomiczne i konstytucyjne Królestwo Polskie ${ }^{11}$. W 1818 r. Aleksander nadał statut konstytucyjny anektowanej w 1812 r. Besarabii.

Wreszcie rosyjski monarcha występował niejednokrotnie jako promotor ustroju konstytucyjnego w Europie. Kiedy Wyspy Jońskie (jako tzw. Republika Siedmiu Wysp) weszły w orbitę wpływów rosyjskich, Aleksander zlecił swemu przedstawicielowi w tym kraju, hr. Georgijowi Močenidze ${ }^{12}$, przygotowanie projektu konstytucji.

biurokracji; zachowało się pięć dotyczących go opinii z lat 1817-1819. Zob. К.С. Чернов, Забытая конституция. „Государственная Уставная Грамота Российской Империи”, Москва 2007, с. 123-127. Siergiej Władimirowicz Mironenko (ur. 1951), historyk rosyjski, autor źródłowych prac dotyczących historii Rosji pierwszej połowy XIX w., w latach 1992-2016 dyrektor Państwowego Archiwum Federacji Rosyjskiej w Moskwie. Kirył Siergiejewicz Czernow, absolwent Państwowego Uniwersytetu w Moskwie, pracę doktorską o konstytucji rosyjskiej z 1820 r. obronił w 2007 r., związany z Instytutem Biznesu i Polityki oraz Uniwersytetem Medycznym w Moskwie.

10 С.В. Мироненко, Страницы тайной истории самодержавия. Политическая история первой половины ХІХ столетия, Москва 1990, с. 68-71. Rozdział poświęcony konstytucji z 1820 r. $\mathrm{w}$ tym opracowaniu jest niemal dosłownym powtórzeniem analogicznego rozdziału ze zbioru Самодержавие и ребормы... Dlatego cytuję go tylko wtedy, gdy odnoszę się do kilku dodanych przez autora fragmentów.

11 Ujęcie porównawcze przedstawia W. Turek, Królestwo Polskie i Wielkie Księstwo Finlandii do 1830 r. Ustrojowopolityczne podobieństwa i różnice, w: System polityczny, prawo, konstytucja i ustrój Królestwa Polskiego 1815-1830, red. L. Mażewski, Radzymin 2013, s. 391-408.

12 Georgij Močenigo, właśc. Giorgio Mocenigo (1762-1839), potomek arystokratycznej rodziny weneckiej osiadłej na wyspie Zakintos, przyjął służbę rosyjską; był ambasadorem Rosji we Florencji (do 1799 r.), w 1802 r. Aleksander I mianował go swoim „pełnomocnym przedstawicielem” przy Republice Siedmiu Wysp. Na tym stanowisku „kierował rosyjską polityką w Republice [...], trzymał w ręku wszystkie nici władzy politycznej, sterował działalnością jońskich organów rządowych”, А.М. Станиславская, Россия и Грециия в конце XVIII - начале XIX вв. Полиӥика России в Ионической республике 1798-1807, Москва 1976, с. 154-155, 160; zob. też: K. Zanou, Beyond „Neo-Hellenic Enlightenment”. Greek intellectuals between the Ionian Islands, Italy and Russia (1800-1830), „CAS Sofia Working Paper Series” (2014), no. 6, s. 7. 
$\mathrm{Na}$ bazie tego projektu, opracowanego przez Močeniga przy udziale ambasadora rosyjskiego w Neapolu Andrieja Italińskiego i kilku innych osób, a następnie poprawionego w Petersburgu, powstała Konstytucja Republiki, przyjęta przez Ciało Prawodawcze 5 grudnia 1803 r. Aleksander, dumny ze swego dzieła, miał się nim później szczycić wobec Napoleona. Niemniej uważnie obserwował, jak funkcjonuje wprowadzony na Wyspach system i w 1806 r. doprowadził do zmodyfikowania konstytucji w duchu autokratycznym ${ }^{13}$. W 1814 r. rosyjski minister spraw zagranicznych Joànis Capodistrias otrzymał zadanie przygotowania projektu konstytucji dla Szwajcarii ${ }^{14}$; w tym samym czasie Aleksander domagał się od Ludwika XVIII zagwarantowania praw konstytucyjnych Francuzom. O niegasnącym zainteresowaniu cara teorią i praktyką konstytucjonalizmu świadczyły rozmowy, jakie prowadził na ten temat $z$ reprezentantami Stanów Zjednoczonych w Petersburgu, osobista korespondencja $z$ Thomasem Jeffersonem i misje dyplomatyczne, podczas których jego współpracownicy dyskutowali o nowych rozwiązaniach ustrojowych (np. rozmowy Nowosilcowa w Londynie w 1805 r. o „urządzeniu wewnętrznym” Niemiec, rozmowy gen. Aleksandra Bałaszowa z Wilhelmem I, królem Wirtembergii i szwagrem Aleksandra, w latach 1817-1818) ${ }^{15}$.

\section{Prace nad projektem Nowosilcowa (1818-1820)}

Propozycje Komitetu Niejawnego, Komisji Kodyfikacyjnej, „Wstęp do zbioru ustaw państwowych" z 1809 r. czy późniejsze pisma Sperańskiego, choć dotyczyły zmian ustrojowych, nie zostały ujęte $\mathrm{w}$ formę ustawy zasadniczej. Przygotowanie projektu „karty konstytucyjnej” dla Rosji Aleksander zlecił Nowosilcowowi po zamknięciu pierwszego sejmu w Warszawie w końcu kwietnia $1818 \mathrm{r}$. Miało się ono odbywać w całkowitej tajemnicy, przy udziale zaledwie kilku osób. Wprawdzie i poprzednie projekty reformatorskie powstawały $\mathrm{z}$ reguły $\mathrm{w}$ wąskim gronie zaufanych doradców cara i zdarzało się, że nie znali ich nawet najwyżsi dygnitarze państwowi ${ }^{16}$, jednak

${ }^{13}$ Le tre costituzioni $(1800,1803,1817)$ delle sette Isole Jonie ed i relativi documenti con l'aggiunta dei due progetti di costituzione del 1802 e 1806 e delle modificazioni e riforme alla costituzione del 1817, Corfu 1849; А.М. Станиславская, op. cit., c. 161-164, 182-204, 248-254 (szczegółowe omówienie prac nad konstytucją, jej treści i modyfikacji z 1806 r.); A. McConnell, Alexander I's Hundred Days. The Politics of a Paternalist Reformer, „Slavic Review” 28 (1969), no. 3, s. 391. W pracach nad projektem konstytucji Wysp Jońskich (prawdopodobnie na późniejszym etapie, po 1803 r.) uczestniczył również Rozenkampf.

14 J.M. Hartley, Is Russia part of Europe? Russian perceptions of Europe in the reign of Alexander I, "Cahiers du monde russe et soviétique” 33 (1992), no. 4, s. 373. Janet M. Hartley (ur. 1954), badaczka dziejów Rosji XVII-XX w., związana z London School of Economics and Political Science.

15 Э. Доннерт, Либеральный конституционализм и конституиионные проекты времени Александра І для Финляндии, Польши и России, w: Славянские народы. Общность истории и культуры, ред. Б.В. Носов, Москва 2000, с. 203-204, 207.

16 Tak było z projektem wykupu chłopów z poddaństwa przez państwo, który pozostał tajemnicą Aleksandra i Arakczejewa, С.В. Мироненко, Страницьь тайной истории..., с. 71. 
tym razem Aleksander przedsięwziął szczególne środki ostrożności. O pracach nad konstytucją nie wiedział nawet wielki książę Konstanty. Nowosilcow dobrał sobie do pomocy francuskiego prawnika Pierre’a Pécharda Deschampsa i księcia Piotra Andriejewicza Wiaziemskiego. O pierwszym z nich niewiele wiadomo, oprócz tego, że w swojej ojczyźnie "nabrał wielkiej wprawy w przygotowywaniu i redagowaniu projektów konstytucyjnych"; ok. 1799 r. został prywatnym sekretarzem Nowosilcowa, a w latach 1807-1808 pracowal jako młodszy pomocnik referendarza w Komisji Kodyfikacyjnej ${ }^{17}$. Drugi - młody, liberalizujący poeta i krytyk literacki, wychowanek Nikołaja Karamzina ${ }^{18}$, przyjaciel Aleksandra Puszkina i Aleksandra Turgieniewa - podjął pracę w warszawskiej kancelarii Nowosilcowa na początku $1818 \mathrm{r}$.

Pierwszy krok stanowiło przygotowanie rosyjskiego przekładu konstytucji Królestwa Polskiego. Zajmował się tym Wiaziemski, który już wcześniej, podczas sejmu, tłumaczył na rosyjski dwa oficjalne wystąpienia monarchy (na otwarcie i zamknięcie obrad). Ponieważ terminy określające pojęcia i instytucje właściwe dla zachodniego konstytucjonalizmu nie miały odpowiedników w języku rosyjskim, zadanie tłumacza było ogromnie trudne. Wiaziemski korzystał częściowo $\mathrm{z}$ terminologii, którą wprowadził do swoich projektów Sperański, konsultował się również z Karamzinem. Kluczowe terminy przełożył sam Aleksander, tłumacząc la constitution przez государственное уложение, a libéral przez законносвободный ${ }^{19}$. Praca nad właściwym projektem rozpoczęła się prawdopodobnie dopiero w końcu 1818 r., kiedy car wezwał Nowosilcowa do Mińska i przez pewien czas odbywał $\mathrm{z}$ nim regularne posiedzenia robocze ${ }^{20}$. Po powrocie Nowosilcow powierzył Deschampsowi rozwinięcie idei monarchy na piśmie. Podczas pobytu w Warszawie w październiku 1819 r. Aleksander zapoznał się z roboczą wersją projektu i wprowadził do niego swoje poprawki. $W$ ten sposób powstała tzw. pierwsza redakcja w języku francuskim: „Précis de la charte constitutionnelle pour l'Empire russe”, licząca ok. 2,5 strony i podzielona na 7 tytułów ${ }^{21}$. Przed samym wyjazdem car przestudiował tekst jeszcze raz, zgłosił kolejne uwagi i polecił przygotowanie ostatecznej wersji konstytucji w ciągu dwóch miesięcy ${ }^{22}$.

17 Idem, Самодержавие и ребормыц.., с. 172.

${ }^{18}$ Karamzin, żonaty z przyrodnią siostrą Piotra Wiaziemskiego, po śmierci teścia objął opiekę nad niepełnoletnim chłopcem, http://biography.5litra.ru/26-petr-vyazemskij-biografiya.html (dostęp: 25.04.2020).

19 G. Vernadsky, ор. cit., s. 81-82; С.В. Мироненко, Самодержавие и реформы..., с. 162 і n., 183.

20 С.В. Мироненко, Самодержавие и ребормыл..., с. 169. Analizując korespondencję i pamiętniki Wiaziemskiego, Mironenko w przekonujący sposób obala tezę Wiernadskiego, że pierwszy projekt rosyjskiej konstytucji powstał już latem 1818 r., ibidem, c. 163-169.

${ }^{21}$ Publikacja tekstu: Th. Schiemann, Eine Konstitution für Russland vom Jahre 1819, „Historische Zeitschrift” 72 (1894), H. 2, s. 65-68 (na podstawie odpisu z raportu konsula pruskiego w Warszawie z 17 października 1819 r.). Omówienie: G. Vernadsky, op. cit., s. 76-77; C.В. Мироненко, Самодержавие и ребормы..., с. 174-177. Tytuły to według dzisiejszej terminologii rozdziały.

22 G. Vernadsky, op. cit., s. 75; С.В. Мироненко, Самодержавие и ребормьл.., с. 173-174. 
Powyższe szczegóły dotyczące ostatnich tygodni pracy nad redakcją „Précis” historycy zawdzięczają raportom konsula pruskiego w Warszawie Juliusa Schmidta, który - jak pisał Stanisław Smolka - zapoznał się z treścią projektu wcześniej niż „biedny monarcha, który go obstalował" i wysłał niezwłocznie odpis ministerstwu w Berlinie ${ }^{23}$. Wkrótce doszło do kolejnego przecieku: 21 listopada 1819 r. liberalny dziennik francuski „Le Constitutionnel”, powołując się na „list z Warszawy dostarczony szczególną drogą", poinformował o pracach nad konstytucją rosyjską i podał najważniejsze postanowienia „Précis”. Dziennikarz podkreślał, że chodzi o wydarzenie, które może stać się „wielką sensacją w Europie” ${ }^{24}$. Berlin i Wiedeń uznały wspomniane doniesienia za wystarczająco poważne, aby polecić swym ambasadorom w Petersburgu zbadanie sprawy na miejscu. Obaj dyplomaci nadesłali jednak uspokajające raporty, zapewniając, że wprowadzenie konstytucji w Rosji jest nierealne ${ }^{25}$.

Druga redakcja konstytucji była, jak się wydaje, dziełem samego Nowosilcowa, ponieważ jego sekretarz Deschamps zmarł niespodziewanie 26 października 1819 r., a Wiaziemski zachował status tłumacza i nie brał udziału w pracy koncepcyjnej. Tekst został wysłany do Aleksandra wiosną 1820 r. Kiedy Wiaziemski pojechał do Petersburga latem tego roku, car wyraził zadowolenie $\mathrm{z}$ dotychczasowych prac i zapowiedział, że przekaże jeszcze Nowosilcowowi pewne uwagi odnośnie do nowej wersji. Mówił jednak również o braku środków finansowych na generalną reformę państwa i o opozycji ze strony ludzi uważających liberalne zasady za źródło anarchii i zaburzeń politycznych w Europie ${ }^{26}$. Ostateczna redakcja, obejmująca 6 tytułów i 191 artykułów, została zaaprobowana przez Aleksandra najprawdopodobniej po jego przyjeździe do Warszawy na obrady drugiego sejmu (13 września - 13 października 1820). Nowosilcow przygotował też projekty dwóch uzupełniających aktów: wstępny manifest i ukaz o wcieleniu Królestwa Polskiego do konstytucyjnego Cesarstwa ${ }^{27}$. Nie wiadomo, czy przedstawił je w tym samym czasie i jak odniósł się do nich Aleksander. Za swoją pracę nad „Gramotą”

${ }^{23}$ S. Smolka, Nowosilcow przed r. 1820, w: idem, Polityka Lubeckiego przed powstaniem listopadowym, wstęp R. Kołodziejczyk, t. 2, Warszawa 1984, s. 326. Nowosilcow utrzymywał bliskie stosunki ze Schmidtem i świadczył mu (nie zawsze bezinteresownie) cenne usługi.

24 „Le Constitutionnel” (21 XI 1819), s. 3; G. Vernadsky, op. cit., s. 77-78; С.В. Мироненко, Самодержавие и реформы..., с. 177 (cytuje artykuł niedokładnie, dodając zdanie wyrażające wątpliwość, którego brak w oryginalnym tekście).

25 Ambasador pruski Reinhold von Schöler przesłał przy tej okazji do Berlina odpis „Précis”, zgodny z kopią dostarczoną wcześniej przez Schmidta, G. Vernadsky, op. cit., s. 78; С.В. Мироненко, Самодержавие и реформын.., с. 178.

26 С.В. Мироненко, Самодержавие и реформы..., с. 182-183. Wiaziemski wkrótce popadł w niełaskę. Wiosną 1821 r. otrzymał zakaz powrotu do Królestwa Polskiego. Złożył wówczas podanie o dymisję ze służby, przyjęte przez cara. W następnych latach znajdował się pod nadzorem tajnej policji.

27 Teksty opublikował Szymon Askenazy w Rosja - Polska 1815-1830, Lwów 1907, s. 175-178 (manifest) i 188-189 (ukaz). 
komisarz pełnomocny został wynagrodzony dobrami w Słonimiu z 125 tys. rubli rocznego dochodu ${ }^{28}$.

Konstytucja była gotowa, jednak car, podobnie jak w przypadku wielu wcześniejszych projektów, nie podjął żadnych dalszych kroków i pozostawił sprawę w zawieszeniu. Co więcej, w następnych latach wydawał się coraz bardziej odchodzić od swych zamysłów reformatorskich. Rękopis pozostał w kancelarii Nowosilcowa, który nie ryzykował już nowych niedyskrecji - w każdym razie żadne informacje o wersji z 1820 r. nie dotarły ani do rządów pruskiego czy austriackiego, ani, w późniejszym czasie, do Mikołaja I i jego otoczenia. Do ujawnienia projektu konstytucji doszło podczas powstania listopadowego, w trakcie porządkowania akt Nowosilcowa przez Komitet Rozpoznawczy badający papiery byłych agentów tajnej policji.

Znaleziona w papierach Nowosilcowa konstytucja Cesarstwa Rosyjskiego z 1820 r. miała dwie wersje językowe: francuską („La Charte constitutionnelle de l'Empire de Russie”) i rosyjską („Государственная уставная грамота Российской империи"). Co ciekawe, wersja rosyjska nie była zwyczajnym przekładem z porównania $\mathrm{z}$ tekstem francuskim wynika, że do niektórych artykułów wprowadzono (świadomie) pewne zmiany merytoryczne. Przemawia to za uznaniem obu redakcji za oryginalne ${ }^{29}$. Na marginesie rękopisu (w obu wersjach językowych) przy poszczególnych artykułach zaznaczono, czy mają one odpowiedniki w konstytucji Królestwa Polskiego z 1815 r., czy też są „,nowe”. Zbieżności redaktor odnotował w przypadku 122 artykułów (na 191). Najczęściej chodziło o dosłowne lub niemal dosłowne powtórzenia; niekiedy polski pierwowzór był modyfikowany lub też zachowywano z niego tylko zewnętrzną formę, zmieniając zawartość. „Nowych” artykułów było $47^{30}$.

Rękopis został opublikowany (w wersji dwujęzycznej) sumptem powstańczego Rządu Narodowego w Warszawie 30 lipca $1831 \mathrm{r}^{31}$ Po zdobyciu miasta

${ }^{28}$ F.W. Thackeray, Antecedents of Revolution. Alexander I and the Polish Kingdom 1815-1825, New York 1980, s. 60. Frank W. Thackeray, amerykański historyk związany z Indiana University Southeast.

${ }^{29}$ Kirył Czernow uważa, że relację oryginał-przekład należy ustalać dla każdego artykułu osobno, $\mathrm{w}$ zależności od tego, jaka norma prawna stanowiła jego podstawę. W przypadku norm zachodnioeuropejskich (francuskich i niemieckich) oryginalna byłaby wersja francuska, w przypadku rosyjskich - rosyjska, Забытая конституция..., с. 30.

${ }^{30}$ Ibidem, c. 58-60.

31 Charte constitutionnelle de l'empire de Russie, Varsovie 1831. Edycja ta (z pominięciem rosyjskiej wersji tekstu) była parokrotnie przedrukowywana przez liberalnych przyjaciół sprawy polskiej na Zachodzie („Le Portfolio ou Collection de documents politiques relatifs à l'histoire contemporaine" 5 (1837), s. 379-419; A. Frank, Projet d'une charte constitutionnelle d'Alexandre Ir empereur de Russie, Paris 1859); tekst rosyjski opublikował Н.К. Шильдер, Император Александр Первыци. Его жизнь и изарствование, т. 4, Санкт-Петербург 1898, приложение VI, с. 499-526. Przedruki edycji warszawskiej i jej odpisy rękopiśmienne (kilka $\mathrm{z}$ nich zachowało się w archiwach rosyjskich) można rozpoznać po błędzie wydawców, którzy w pośpiechu opuścili jeden z artykułów w tekście francuskim - ma on w nich 190 artykułów zamiast 191; por. К.С. Чернов, Забытая 
feldmarszałek Iwan Paskiewicz skonfiskował i wysłał do Moskwy wszystkie niesprzedane egzemplarze (1578 z 2000 wydrukowanych). Zostały one komisyjnie spalone na polecenie Mikołaja I, który obawiał się negatywnego wpływu publikacji na kadrę oficerską. „Fakt wydrukowania tego dokumentu - pisał do Paskiewicza - jest nader przykrym; na 100 ludzi wśród oficerów naszych, 90-ciu przeczyta i nie zrozumie lub pogardzi nim, lecz 10-ciu z nich pozostanie on w pamięci, będą go dyskutowali, a co najważniejsza - nie zapomną go" ${ }^{32}$. Rękopis, również przejęty przez Rosjan, trafil do tajnego archiwum cesarskiego ${ }^{33}$. Historycy uzyskali do niego dostęp dopiero za panowania Mikołaja II. Nowe, krytyczne wydanie obu wersji językowych opublikował w 1903 r. profesor Uniwersytetu w Berlinie Theodor Schiemann ${ }^{34}$.

\section{Ustrój Cesarstwa Rosyjskiego według „Ustawnoj Gramoty”}

Konstytucja Cesarstwa Rosyjskiego z 1820 r., jak wskazywały na to nawet adnotacje redaktorskie na rękopisie, nosiła wyraźne podobieństwo do konstytucji Królestwa Polskiego. Wrażenie to pogłębiały paralelizm niektórych części ${ }^{35}$ i licznych artykułów oraz zapożyczenia z polskiej terminologii (np. sejm - сейм, poseł - посол). Dokładniejsza analiza pozwala jednak zauważyć istotne różnice ${ }^{36}$. „Gramota” bardziej podkreślała pozycję monarchy i ograniczała rolę organów przedstawicielskich, a przede wszystkim łączyła rozwiązania ustrojowe zaczerpnięte $\mathrm{z}$ polskiej konstytucji z koncepcją federalistyczną. Ta ostatnia stanowiła najbardziej radykalne novum projektu z $1820 \mathrm{r}$.

Cesarstwo Rosyjskie miało dzielić się na namiestnictwa funkcjonujące jako swego rodzaju kraje konstytucyjne $\mathrm{w}$ ramach jednego Imperium. Monarchę

конституция..., с. 16. Inny, nietypowy odpis przechowywany jest w oddziale rękopisów BJ (obecna sygn.: 6980 I, dawna: Oct. 22). Zawiera on wstęp ministra Horodyskiego w języku polskim i francuskim (z edycji warszawskiej) oraz bezbłędny francuski tekst konstytucji (191 artykułów). W aktach BJ nie zachowały się informacje, kiedy i w jaki sposób rękopis ten trafił do jej zbiorów. Być może został sporządzony jeszcze w okresie powstania przez osobę mającą dostęp nie tylko do drukowanej edycji, ale także do oryginalnego dokumentu.

32 S. Cieszkowski, Aleksander I a Konstytucja, Warszawa-Lwów 1909, s. 92-93; Н.К. Шильдер, op. cit., c. 465-466, примечание 190.

33 Obecnie znajduje się w: Российский государственный архив древних актов, ф. 3, раз. III, д. 25.

${ }^{34}$ La Charte Constitutionnelle de l'Empire de Russie d'après l'original des archives de St. Pétersbourg, ed. Th. Schiemann, Berlin 1903. Wśród współczesnych edycji można wymienić Конституичионные проекты в России XVIII - начало XX в., ред. С. Бертолисси, А.Н. Сахаров, Москва 2000, приложение 27; Конституционные проекты России 1799-1825, ред. О.Г. Субботин / Соnstitutional Projects of Russia 1799-1825, ed. O. Subbotin, München 2007, s. 79-128.

35 Tekst dzielił się na tytuły (titre/ глава), rozdziały (chapitre/ отделение), sekcje (section/ разряд) i artykuły (article/ статья). Tytuły II, IV i V w „Gramocie” odpowiadały tytułom III, IV i V konstytucji Królestwa.

36 Źródła i treść konstytucji omawiają dokładnie G. Vernadsky (op. cit.); С.В. Мироненко (Самодержавие и ребормы..., Страницы тайной истории...) і К.С. Чернов (Забытая конституция...). 
reprezentował w nich namiestnik. „Gramota” wprowadzała system podwójnych organów władzy - centralnych i regionalnych: Radzie Państwa (Stanu) miały odpowiadać na szczeblu regionalnym rady namiestnictw, sejmowi generalnemu - sejmy namiestnictw, Senatowi - departamenty Senatu dla poszczególnych namiestnictw etc. Rady składały się z szefów poszczególnych działów administracji oraz innych osób mianowanych przez monarchę bądź delegowanych przez ministerstwa. Podobnie jak w Królestwie Polskim, dzieliły się na Zgromadzenie Ogólne i Radę Administracyjną (na szczeblu centralnym była to Rada Państwa tożsama z Komitetem Ministrów). Do ich kompetencji należały: przygotowywanie projektów ustaw, sądownictwo administracyjne i nadzór nad administracją (wspólnie z Senatem). Komitet Ministrów stanowił instancję zwierzchnią wobec namiestników i Rad Administracyjnych w namiestnictwach i mógł anulować ich postanowienia. Dwuizbowe sejmy, składające się z senatorów (izba wyższa) oraz posłów i deputowanych (izba niższa), miały „współdziałać” (concourirl содействовать) z monarchą w ustanawianiu prawa. Prawa wyborcze "Gramota” przyznawała posesjonatom (również nieposiadającym szlachectwa), „wyróżniającym się obywatelom", kupcom dwóch pierwszych gildii i właścicielom warsztatów rzemieślniczych.

System elekcji był dość skomplikowany. Kandydatów do sejmów namiestnictw i sejmów w miastach stołecznych ${ }^{37}$ wybierały szlacheckie sejmiki i nieszlacheckie zgromadzenia gminne (po trzech), a monarcha mianował $\mathrm{z}$ tej liczby dwie trze$\mathrm{cie}^{38}$. Izba senatorska, złożona $\mathrm{z}$ dożywotnich nominatów, nie mogła przekraczać $1 / 4$ liczebności izby niższej. Sejm zbierał się co 3 lata na 30 dni. Jego kompetencje i tryb pracy były określone podobnie jak w konstytucji Królestwa; na czas obrad posłom przysługiwały immunitet i wolność wyrażania opinii. Kadencja wynosiła 6 lat, z odnowieniem połowy składu co 3 lata. Kandydatów na sejm generalny wybierały sejmy namiestnictw i miast stołecznych, monarcha mianował $\mathrm{z}$ nich połowę. Kadencja wynosiła w tym wypadku 10 lat, z odnowieniem połowy składu przy każdym sejmie, czyli co 5 lat. Izbę wyższą sejmu generalnego tworzył (zależnie od miejsca obrad) petersburski lub moskiewski departament Senatu i wskazani przez monarchę senatorowie z innych departamentów. „Gramota” wprowadzała zasadę niezawisłości sądownictwa. Sędziów mianował monarcha. Najwyższy trybunał w namiestnictwie pełnił rolę III (ostatniej) instancji w sprawach cywilnych i karnych; najwyższy trybunał Cesarstwa wyrokował wyłącznie w sprawach o zbrodnię stanu oraz dotyczących przestępstw najwyższych urzędników państwowych. Sejmy i sądy w namiestnictwach stanowiły najwyższą władzę regionalną, natomiast

37 Dwie stolice Cesarstwa - Petersburg i Moskwa - były wydzielone ze struktury namiestnictw.

${ }^{38}$ Dawałoby to panującemu możliwość manewrowania proporcją przedstawicieli szlachty i nieszlachty w izbie niższej. W Królestwie Polskim wybory do sejmu były bezpośrednie, natomiast system podobny do opisanego wyżej konstytucja z 1815 r. stosowała do nominacji na urzędy administracyjne (co zresztą pozostało na papierze), por. G. Vernadsky, op. cit., s. 197, 207. 
w hierarchii władz wykonawczych widoczna była przewaga organów centralnych nad organami namiestnictw. W tej kwestii „Gramota” przyjmowała centralistyczne wzory administracji francuskiej ${ }^{39}$.

W przeciwieństwie do konstytucji Królestwa Polskiego i innych konstytucji z początku XIX w. „Gramota” potwierdzała i podkreślała władzę suwerena jako fundamentalną zasadę życia publicznego ${ }^{40}$. Uznawała, że „suwerenność jest niepodzielna i jest w osobie monarchy" (art. 11), który w konsekwencji pozostaje „jedynym źródłem każdej władzy cywilnej, politycznej, prawodawczej i wojskowej w Cesarstwie”, a „każda władza wykonawcza, administracyjna i sądownicza może pochodzić wyłącznie od niego" (art. 12). Sformułowania te wykluczały całkowicie ideę suwerenności ludu. Uprawnienia monarchy ograniczały jedynie sejmy, powołane do „współdziałania” z nim w stanowieniu prawa. Wobec religii panującej władca Cesarstwa występował jako „naczelny zwierzchnik” (chef supérieur) верховный глава) Rosyjskiej Cerkwi Prawosławnej ${ }^{41}$.

Katalog praw obywatelskich w rosyjskiej konstytucji przedstawiał się podobnie jak w konstytucji Królestwa Polskiego. „Gramota” stanowiła dodatkowo, że samowolne aresztowanie będzie karane zgodnie z Kodeksem karnym i wprowadzała równy dostęp do sprawowania urzędów publicznych. Postanowienia te nie dotyczyły chłopów poddanych, o których ustawa w ogóle nie wzmiankowała.

W kwestiach szczegółowych „Gramota” odsyłała do statutów organicznych, które miały zostać przygotowane i ogłoszone w późniejszym terminie. Nie określała również granic ani liczby namiestnictw ${ }^{42}$. Spis zachowany w papierach Komitetu 6 Grudnia $1826^{43}$, który większość badaczy uważa za uzupełnienie rękopisu z kancelarii Nowosilcowa, wymieniał 12 namiestnictw obejmujących od 3 do 5 guberni. Nie było wśród nich ani Królestwa Polskiego, ani Wielkiego Księstwa Finlandii ${ }^{44}$.

39 Ibidem, s. 178, 242; К.С. Чернов, Забытая конституичя..., с. 112. Zdaniem Czernowa „u podstaw organizacji administracji w Gramocie leżała zasada unitaryzmu".

40 G. Vernadsky, op. cit., s. 131; К.С. Чернов, «Правительственный конституционализм» первой четверти XIX в. (на примере „Государственной уставной грамоты Российской империи”), „Труды Исторического факультета Санкт-Петербургского университета” 3 (2012), № 11, c. 172-173.

${ }^{41}$ Zdaniem Wiernadskiego termin „religia panująca” (religion dominante) był tylko dekoracją, a "Gramota” dawała Cerkwi mniej niż polska konstytucja Kościołowi katolickiemu, gdyż nie gwarantowała jej własności ani nie zapewniała biskupom miejsc w Senacie, La Charte..., s. 146$148,183$.

42 Wedle „Précis” miało być ich 10.

43 Tajny komitet powołany przez Mikołaja I, który zajmował się m.in. badaniem papierów znalezionych po śmierci Aleksandra I w jego gabinetach w Pałacu Zimowym, Carskim Siole i pałacu na Kamiennym Ostrowie pod Petersburgiem.

${ }^{44}$ G. Vernadsky, op. cit., s. 39; С.В. Мироненко, Самодержавие и реформы..., с. 192-193. Na stolice namiestnictw wyznaczone były: Psków, Witebsk, Kijów, Odessa, Archangielsk, Twer, Tuła, Orenburg, Kazań, Tyflis, Tomsk i Wilno. 


\section{Cele Aleksandrowskiej reformy}

Wśród autorów prac poświęconych rosyjskiej konstytucji z 1820 r. dominuje opinia, że nie naruszała ona autokratycznej władzy monarchy. Już Aleksander Pypin stwierdził, że odpowiadała ona charakterowi Aleksandra, który „przy wszystkich liberalnych marzeniach, zazdrośnie chronił swoją władzę" ${ }^{45}$. Wedle Siergieja Mironenki „Gramota” miała charakter patriarchalny: car zachowywał wpływ na wszystkie ważne procesy w państwie, żadna kwestia nie mogła być rozwiązana bez jego udziału. Tego samego zdania jest niemiecki historyk i slawista Erich Donnert ${ }^{46}$. Kirył Czernow, przedstawiciel najmłodszego pokolenia rosyjskich historyków i autor monografii o „zapomnianej konstytucji”, twierdzi wręcz, że jej celem było umocnienie samodzierżawia i niczym nieograniczonego statusu władzy monarszej, a mechanizm konstytucyjny miał służyć stworzeniu prostego, spójnego wewnętrznie i sprawnego systemu do realizacji prerogatyw panującego. Zdaniem tego autora Aleksander przejął z zachodniego konstytucjonalizmu jedynie technologię potrzebną do zmodernizowania tradycyjnej rosyjskiej autokracji i przekształcenia jej w absolutyzm, zdolny do efektywnego kierowania procesami społecznymi i politycznymi ${ }^{47}$. Polemizując $\mathrm{z}$ opinią, że reforma miała zmienić Rosję w państwo konstytucyjne w rozumieniu zachodnim, Czernow dowodzi, że „Gramota” przyznawała organom administracyjnym nie tyle władzę, co funkcje, a sejm sprowadzała do instytucji zajmującej się zbieraniem i opracowaniem informacji z regionów oraz aprobowaniem inicjatyw prawodawczych monarchy ${ }^{48}$.

Część historyków uważa, że podstawowym celem Aleksandra nie było stworzenie systemu konstytucyjnego, tylko reforma administracji. Teza taka pojawiała się zresztą już we współczesnych źródłach. Ambasador austriacki w Petersburgu Louis Lebzeltern pisał w 1820 r. do Klemensa von Metternicha, że projekt rosyjskiej konstytucji jest niczym więcej niż „dwudziestym wariantem planu podziału Rosji na 8 wielkich namiestnictw, do czego już w 1816 byli wyznaczeni generałowie" ${ }^{49}$. Wedle relacji ministra policji Bałaszowa reforma miała dotyczyć struktury zarządzania. Car zamierzał podzielić administrację Imperium na dwa sposoby: „jednym urzędnikom powierzyć ministerstwa, drugim - kierowanie regionami, sobie zaś pozostawić władzę nad całością, tak aby poprzez osobisty nadzór nad

45 А.Н. Пыпин, Общественное движение при Александре I, изд. 5, Петроград 1918, с. 379.

46 С.В. Мироненко, Самодержавие и реформы..., с. 196-197; Э. Доннерт, ор. сіt., с. 206.

47 К.С. Чернов, Забытая конституция..., с. 11, 80, 112; idem, «Правительственный конституционализм»..., с. 177.

48 К.С. Чернов, Забытая конституиия..., с. 93-95, 127; idem, «Правительственный конституционализм»..., с. 176. Przedstawienie projektu prawa sejmowi, który mógł je przyjąć lub odrzucić, miało być w tym ujęciu „testem” na wybranej grupie. O wyłącznie doradczej roli sejmów w „Gramocie” pisze również F.W. Thackeray, Antecedents of Revolution..., s. 58.

49 Cyt. za: G. Vernadsky, op. cit., s. 65-66. 
ich działalnością, badanie sprawozdań i kontrolowanie jednych przez drugich nadawać całej państwowej machinie właściwy kierunek" ${ }^{\prime 5}$. Pogląd, że Aleksander pojmował konstytucję inaczej, niż rozumiano ją na Zachodzie, i że jego celem była reorganizacja czysto administracyjna, sformułował jako pierwszy autor klasycznego studium o Sperańskim, emigracyjny historyk rosyjski Marc Raeff ${ }^{51}$. Podobne stanowisko zajmuje Frank Thackeray, który uważa, że rosyjski monarcha widział w konstytucjonalizmie nie abstrakcyjne zasady proklamujące suwerenność ludu i system reprezentacyjny, ale drogę do restrukturyzacji państwowej administracji, usprawnienia aparatu władzy i osadzenia go na fundamencie prawa oraz wprowadzenia precyzyjnych procedur administracyjnych i sądowych ${ }^{52}$.

Zgodnie z powyższą interpretacją także pomysł podziału Cesarstwa na namiestnictwa nie zrodził się $\mathrm{z}$ teorii federalistycznych, ale $\mathrm{z}$ tendencji do wzmocnienia władzy administracyjnej i policyjnej. Nie oznaczał więc rozdrobnienia Rosji, ale jej konsolidację $e^{53}$. Wiernadski posuwa się do stwierdzenia, że podobnie jak instytucje konstytucyjne stały się w "Gramocie” instytucjami quasi-konstytucyjnymi (simili-constitutionnelles), zasady federalizmu przeobraziły się w niby-federalizm (simili-fédéralisme). Dostrzega w nich natomiast oryginalną i interesującą próbę rozwiązania problemu relacji między centrum a peryferiami Cesarstwa i przezwyciężenia separatyzmów w regionach przygranicznych ${ }^{54}$. Celem, jak pisze Donnert, było organiczne wcielenie "okrain” $\mathrm{z}$ ich historycznymi prawami w strukturę wielonarodowego Imperium ${ }^{55}$.

Zadając pytanie o intencje Aleksandra I, nie można pominąć okoliczności, że „Gramota” była jedynym projektem konstytucyjnym w Europie, który powstał wyłącznie z inicjatywy panującego, bez żadnych nacisków zewnętrznych lub konieczności liczenia się z nastrojami rządzonych. Abstrahując od sporu, kiedy w Rosji pojawił się liberalizm ${ }^{56}$, pewne jest, że nieliczne kręgi liberalizującej opozycji politycznej w epoce aleksandrowskiej ani nie były w stanie wymusić ustrojowych reform, ani nawet zapewnić wystarczającego zaplecza politycznego do ich przeprowadzenia. Jak zresztą wiadomo, obawy przed ruchem rewolucyjnym, które

${ }^{50}$ Суt. zа: С.В. Мироненко, Самодержавие и реформық..., с. 179-180.

${ }^{51}$ Zob. A. McConnell, op. cit., s. 385, przypis 49. W tym kontekście warto też zwrócić uwagę na intersujące analizy Wiernadskiego dotyczące znaczenia, w jakim zostały użyte w "Gramocie” niektóre terminy francuskie. Nation i national odnoszą się tam do państwa (Cesarstwa Rosyjskiego), a nie do ludu (narodu rosyjskiego), G. Vernadsky, op. cit., s. 200.

52 F.W. Thackeray, Antecedents of Revolution..., s. 53. Część historyków konsekwentnie broni przeciwnej opinii, uważając, że Aleksandrowi chodziło o głębszą transformację, oznaczającą przejście do nowego „stadium cywilizacyjnego", zob. np.: А.Н. Сахаров, Конституционные проекты и цивилизационные судьбы России, w: Конституционные проекты в России.., с. 62.

${ }^{53}$ G. Vernadsky, op. cit., s. 46.

${ }^{54}$ Ibidem, s. 157.

55 Э. Доннерт, ор. cit., с. 206.

${ }^{56}$ Niektórzy badacze, jak niemiecki historyk Europy Środkowo-Wschodniej Peter Scheibert, uważają, że nastąpiło to dopiero w latach 1837-1864, zob. ibidem, c. 189. 
pojawiły się u Aleksandra w 1820 r., nie skłoniły go do przyspieszenia planów reformatorskich, lecz przyczyniły się do ich zaniechania.

Uporczywość i konsekwencję, z jaką Aleksander wracał do projektów reformy, trudno wytłumaczyć bezinteresowną chęcią zrzeczenia się niektórych prerogatyw monarszych na rzecz poddanych. Ponadto, jak wyżej wspomniano, wiele przemawia za tym, że system zaprojektowany w „Gramocie” miał usprawnić czy nawet wzmocnić władzę panującego, a nie ją uszczuplić. Czy jednak rosyjski autokrata rzeczywiście potrzebował wzmocnienia swojej pozycji i chciał osiągnąć ten cel drogą ustrojowej „pieriestrojki”?

Już Smolka zwrócił uwagę, że Aleksander od początku swego panowania musiał dzielić się władzą z oligarchią „petersburskich salonów” i że „pragnął zerwać te pęta, ujrzeć się samowładcą w rzeczywistym znaczeniu" "57. Późniejsze badania nad historią Rosji potwierdziły intuicję współtwórcy krakowskiej szkoły historycznej. Władza carska, chociaż od 1715 r. określona formalnie jako „niczym nie ograniczona i przed nikim nie odpowiedzialna", była taka tylko teoretycznie. Zaraz po śmierci Piotra I rozpoczął się okres przewrotów pałacowych. Wobec braku legalnych mechanizmów sukcesji kandydaci i kandydatki do tronu musieli zabiegać o poparcie elity arystokratyczno-wojskowej, a głównym „argumentem prawnym” pozostawały oddziały gwardyjskie. Walka arystokracji dworskiej o utrwalenie swoich wpływów oraz zabezpieczenie się przez samowolą panującego i jego faworytów okazała się skuteczna ${ }^{58}$. Za czasów Katarzyny II, jak pisze Richard Pipes, „monarchia rosyjska stała się w dużej mierze zakładnikiem grup, które sama powołała do życia. Atrybuty cesarskiej wszechwładzy służyły tylko do ukrycia jej rozpaczliwej słabości - oraz zamaskowania rzeczywistej władzy dworian i czynowników"59. John P. LeDonne podkreśla, że pozycję cara poważnie osłabiała dekoncentracja administracji państwowej. Zgodnie $\mathrm{z}$ osiemnastowieczną tradycją każdy resort posiadał znaczną autonomię; nie istniał urząd premiera, a gabinet ministrów nie funkcjonował jako ciało zbiorowe. Dekoncentracja ta „służyła interesom elity politycznej, ponieważ ułatwiała podział łupów - podstawę niepisanego kontraktu, dzięki któremu owa elita uznawała i sławiła «autokrację» panującego". Zdaniem cytowanego badacza rola cara sprowadzała się w gruncie rzeczy do funkcji „wielkiego inspektora generalnego" Cesarstwa. Podjęta przez Aleksandra próba wzmocnienia realnej władzy monarchy $\mathrm{w}$ terenie poprzez delegowanie tam generał-gubernatorów zakończyła się niepowodzeniem - jego reprezentanci stali się ostatecznie lokalnymi inspektorami: wizytowali regiony, zadawali pytania, sprawdzali rachunki,

57 S. Smolka, Nowosilcow..., s. 260.

58 Zob. C.В. Кодан, Г.Е. Владимирова, Политико-идеологические и организационно-правовые предпосылки создания Основных государственных законов Российской империи (XVIII первая четверть ХІХ вв.), „Genesis. Исторические исследования” 2 (2013), № 4, с. 134-171, https://nbpublish.com/library_read_article.php?id=745 (dostęp: 25.04.2020).

59 R. Pipes, Rosja carów, tłum. W. Jeżewski, Warszawa 2006, s. 142; por. A. Barańska, op. cit., s. $66-67$. 
przyjmowali skargi, które przepisowo mieli przedstawić odpowiedniemu ministrowi, aby ten odpowiedział, co mu się będzie podobało. Stwarzało to jedynie fikcję koncentracji obu władz (cesarskiej i lokalnej), której w rzeczywistości nie było ${ }^{60}$.

Interesujący element do dyskusji o układzie władzy za czasów Aleksandra wnosi studium Allena McConnella, poświęcone pierwszym miesiącom jego panowania. Autor przedstawia w nim liczne argumenty na rzecz tezy, że młody monarcha, uwikłany w spisek przeciw swemu ojcu, był początkowo marionetką w rękach jego zabójców. Rolę pierwszej osoby w państwie odgrywał Piotr Aleksiejewicz Pahlen, gubernator wojskowy Petersburga i jeden z przywódców spisku. To właśnie Pahlen miał wymusić na zastraszonym i niezdolnym do oporu Aleksandrze pierwsze decyzje: amnestię dla więźniów politycznych, potwierdzenie Karty Szlacheckiej wydanej przez Katarzynę II i inne. W dalszych planach organizatorów zamachu na Pawła I leżało uzyskanie uprawnień prawodawczych dla Senatu, a być może również konstytucji ograniczającej władzę cesarską i gwarantującej pozycję oligarchii. McConnell zdecydowanie odrzuca wersję, wedle której „młody, idealistyczny władca, pragnący fundamentalnych reform, został powstrzymany przez konserwatyzm szlachty”. W jego ujęciu konstytucji życzyła sobie „silna grupa ludzi doświadczonych i bezwzględnych”, a car bronił swojej autokratycznej władzy tak, jak potrafił ${ }^{61}$. Dopiero dymisja i usunięcie z Petersburga Pahlena (17 czerwca 1801 r.) - najważniejsza, zdaniem McConnella, decyzja polityczna Aleksandra - pozwoliły mu "stać się panem we własnym domu”. Zaczął wówczas wzmacniać autokrację, pozornie po to, aby łatwiej przeprowadzić reformy, faktycznie - aby wycofać się z zapowiedzi, do których został zmuszony ${ }^{62}$. W późniejszych latach podjął projekty reformatorskie i konstytucyjne już na własną rękę, nie doprowadził ich jednak do skutku, ponieważ do końca życia nie pokonał traumy z pierwszego okresu rządów.

Nawet gdy przyjmie się, że rola Pahlena została wyolbrzymiona przez autora przedstawionego opracowania, nie ulega wątpliwości, że nad całym panowaniem Aleksandra ciążyło wspomnienie o okolicznościach uzyskania korony. Jako świadek i w pewnej mierze współuczestnik spisku dworskiego miał okazję poznać z bliska jego mechanizm - dlatego też nigdy nie uwolnił się od lęku, że może pewnego dnia podzielić los ojca. Paweł I zginął nie dlatego, że był okrutny i despotyczny, ale dlatego, że ofiarami jego despotyzmu bywali zbyt często przedstawiciele elity państwowej. Wyrok na niego wydali nie radykałowie szermujący hasłami rewolucji francuskiej, ale wysokiej rangi urzędnicy i wojskowi Cesarstwa. Aleksander otrzymał w ten sposób lekcję, że także autokrata musi znać i respektować granice swojej władzy. Nie jest więc bezzasadne przypuszczenie, że największe zagrożenie dla swej

60 J.P. LeDonne, op. cit., s. 30-31.

61 A. McConnell, op. cit., s. 378-379. Allen McConnell (1923-2009), amerykański historyk dziejów Rosji i ZSRR.

${ }^{62}$ Ibidem, s. 384. 
pozycji widział odtąd w „petersburskiej oligarchii” i że jeden z głównych celów jego projektów reformatorskich stanowiło jej rozbicie i pozbawienie wpływów.

Hipotezę tę potwierdza niechętny i podejrzliwy stosunek Aleksandra do Senatu. Organ ten nie był wprawdzie zaangażowany w konspirację przeciw Pawłowi I w spisku uczestniczyło czynnie tylko dwóch jego członków: Nikołaj i Walerian Zubowowie, a dwóch innych wiedziało o jego istnieniu - stanowił jednak w oczach młodego monarchy jeden $\mathrm{z}$ głównych bastionów oligarchii ${ }^{63}$. Jeszcze $\mathrm{w}$ okresie wpływów Pahlena Aleksander wydał dekret (5 czerwca 1801 r.) wzywający senatorów do przedstawienia raportu o przysługujących im prawach i obowiązkach; celem miało być podniesienie Senatu z „poniżenia”, w jakim się znalazł za poprzedniego panowania. Senator Aleksander Woroncow, pozostający od kilku lat poza służbą publiczną i powszechnie szanowany, otrzymał polecenie przygotowania „Karty narodu rosyjskiego” („Всемилостивейшая Жалованная Грамота российскому народу") - swego rodzaju manifestu konstytucyjnego. Car wycofał się jednak szybko z tych projektów - „Karta”, skrytykowana przez Nowosilcowa na posiedzeniu Komitetu Niejawnego, została odłożona ad acta, natomiast ukaz o Senacie, wydany 8 września 1802 r., ograniczał się do potwierdzenia jego dotychczasowych kompetencji. Postulaty senatorów nie zostały uwzględnione, poza jednym, jakim było przyznanie im tzw. prawa remonstracji - zgłaszania monarsze ustaw wymagających zmiany z powodu niezgodności praw ${ }^{64}$. Jednak już pierwsza próba skorzystania z tego uprawnienia wywołała bardzo ostrą reakcję Aleksandra, który odrzucił senacki wniosek ${ }^{65}$. LeDonne uważa, że incydent ten wyraźnie dowodzi, iż car był zazdrosny o swoją autokratyczną władzę i buntował się przeciw ograniczaniu jej przez rządzącą elitę, „której zawsze czuł się więźniem”66.

Idee reformy Senatu, rozrzucenia jego członków po różnych prowincjach Cesarstwa ${ }^{67}$ i utworzenia generalnych gubernatorstw bądź namiestnictw obsadzonych przez ludzi całkowicie lojalnych wobec Aleksandra i cieszących się jego zaufaniem były stałym motywem w jego projektach reformatorskich - od okresu

${ }^{63}$ Ibidem, s. 376, przypis 10. Kwestia istnienia czy nieistnienia tzw. partii senatorskiej (posiadającej określony program działania) jest w tym wypadku drugorzędna, chodziło bowiem nie tyle o Senat jako instytucję, ile o środowisko.

${ }^{64}$ Zob. ibidem, s. 386-390.

${ }^{65}$ Remonstrację wniósł w 1803 r. senator Seweryn Potocki. Dotyczyła ona sprzeczności pomiędzy dekretem o 12-letniej służbie wojskowej podoficerów wywodzących się ze szlachty a Kartą Szlachecką. Aleksander miał wpaść wtedy w furię. С.В. Мироненко, Самодержавие и реформы..., c. 189; por. S. Cieszkowski, op. cit., s. 38-39; A. McConnell, op. cit., s. 390; J.P. LeDonne, op. cit., s. 15. Relacje między Aleksandrem a Senatem i sens projektów dyskutowanych w latach 1801-1803 są różnie interpretowane w historiografii. Niektórzy badacze, jak Hartley, dostrzegają $\mathrm{w}$ propozycjach senackich tendencje do ograniczenia samodzierżawia inspirowane liberalizmem zachodnioeuropejskim (op. cit., s. 377-378), inni, jak Smolka, dążenie do uprawomocnienia rządów oligarchii (Nowosilcow..., s. 251-252, przypis, 255-256, przypis).

${ }^{66}$ J.P. LeDonne, op. cit., s. 15.

${ }^{67}$ Dyskutowane już w maju 1802 r. na posiedzeniu Komitetu Niejawnego, S. Smolka, Nowosilcow..., s. 256. 
dyskusji w Komitecie Niejawnym aż do „Gramoty”, w której uzyskały najbardziej dojrzałą postać. „Oligarchia” miała przez to stracić swoją władzę na rzecz monarchy. Nawet jeśli organy reprezentacyjne przewidziane w "Gramocie” ograniczały w pewien sposób autokrację, były to ograniczenia znacznie mniejsze od tych, które narzucał „niepisany” kontrakt z elitą urzędniczo-wojskową. Projekt z 1820 r. nie dawał zresztą sejmom możliwości przekształcenia się $\mathrm{w}$ realną siłę polityczną zapobiec temu miały stosunkowo skromne kompetencje, krótki czas obrad oraz połączenie systemu wyborów i nominacji. Tego ostatniego zażądał od Nowosilcowa sam Aleksander, argumentując, że w przeciwnym razie elektorzy mogliby wybrać „każdego, kogo tylko zechcą”. Szczegół ten zasługuje na uwagę również dlatego, że zastrzegając sobie prawo do kontroli nad składem „reprezentacji narodu”, car zdradził jednocześnie, gdzie dostrzega największe źródło zagrożenia - jako przykład kandydata nie do przyjęcia spontanicznie wskazał Nikitę Panina ${ }^{68}$.

Panin, w 1800 r. wicekanclerz Cesarstwa, był do momentu swego wygnania z Petersburga jednym z głównych uczestników konspiracji przeciw Pawłowi I; po jego śmierci wrócił do stolicy, objął ponownie stanowisko w Kolegium Spraw Zagranicznych i, wraz z Pahlenem, wywierał duży wpływ na decyzje Aleksandra w pierwszych miesiącach jego panowania. Trzy miesiące po upadku Pahlena otrzymał urlop, który miał się okazać bezterminowy ${ }^{69}$. Tego właśnie środowiska - słusznie czy niesłusznie - obawiał się Aleksander znacznie bardziej niż „demagogów” o radykalnych poglądach. Przedmiotem jego lęku nie były spiski typu rewolucyjnego, rozwijające się w ponapoleońskiej Europie, ale to, co znał z autopsji - spisek dworski zmierzający do usunięcia $\mathrm{z}$ tronu niewygodnego monarchy. Rozalia z Lubomirskich Rzewuska, znająca dobrze i samego cara, i jego otoczenie, wyraziła na ten temat dość znamienny pogląd:

[Aleksander] uważał się za liberała, bo nie chciał żadnej władzy pośredniej między suwerenem a ludem niewolników. Szlachta rosyjska była mu wstrętna. Daleki od uszanowania szlachetnej dumy, którą wywołuje w znakomitej rodzinie wspomnienie o dawnych zasługach, cesarz nimi gardził, szanował tylko tych, którzy wyróżniali się stopniem wojskowym. Takich przyzywał do siebie, i faworyzował szczególnie ludzi bez nazwiska i bez stanu, których jedyną zasługą było niejasne pochodzenie oraz to, że wydobyli się z niego dzięki wszechmocnej woli. Cesarz pamiętał, że między zabójcami Piotra III i Pawła I figurowały znakomite nazwiska. Być może to wspomnienie wzbudziło w nim osobliwą nieufność do arystokracji. Przy okazji koronacji cesarza ktoś napisał: „Widziałem, jak szli przed nim

68 G. Vernadsky, op. cit., s. 198, przypis 1; С.В. Мироненко, Самодержавие и ребормы..., с. 188189.

${ }^{69}$ Obawy Aleksandra przed Paninem były tak silne, że poddał go ścisłej inwigilacji, a wkrótce zakazał mu pojawiania się „w tym samym mieście, w którym przebywa cesarz”. Kiedy w $1806 \mathrm{r}$. smoleńska szlachta wybrała Panina na naczelnika ziemskiej milicji w tej guberni, jego wybór został natychmiast unieważniony decyzją z Petersburga. А.Г. Брикнер, Панин, граф Никита Петрович, w: Русский биоргафический словарь..., т. 13, Санкт-Петербург 1902, с. 205-211; A. McConnell, op. cit., s. 383-384. 
mordercy jego dziadka, obok niego - mordercy ojca, a za nim, zapewne, jego przyszli zabójcy". Niestety, ta przepowiednia nieomal się spełniła ${ }^{70}$.

Komentując epizod ze zmianą systemu wyborów $\mathrm{z}$ bezpośredniego na pośredni, Mironenko zauważa, że za każdym razem, kiedy Aleksander spotykał się z czymś, co „ograniczało jego możliwości działania po swojemu”, odkładał na bok swoje teoretyczne (czytaj: liberalne) idee ${ }^{71}$. W „Gramocie” idee te zostały konsekwentnie podporządkowane pragmatyce władzy. Aleksander był w tej kwestii bezkompromisowy. „Kiedy tylko dostrzegał atak na podstawy swojej władzy - pisze Thackeray reagował szybko i z całą siłą [...]. Konstytucja, w jego rozumieniu, istniała dla dobra cesarza (i państwa), a nie jako osłona do podejmowania ataków na autokrację"72.

Znamienny jest także stopień utajnienia projektu konstytucyjnego. Wcześniejsze prace nad reformami odbywały się w warunkach większej jawności - propozycje Sperańskiego były dość szeroko znane (i krytykowane) w kręgach rosyjskiej elity politycznej. O „Gramocie” wiedzieli tylko Nowosilcow, Wiaziemski i - być może - pojedyncze osoby, którym pierwszy lub drugi z nich ujawnił jej treśćc ${ }^{73}$. Aleksander najprawdopodobniej zdradził sekret tylko najbardziej zaufanemu ze swych współpracowników - Arakczejewowi ${ }^{74}$. Taki sposób działania przypominał raczej przygotowania do zamachu stanu niż ogłoszenia nowej ustawy przez monarchę dysponującego (przynajmniej teoretycznie) pełnią władzy prawodawczej.

\section{Królestwo Polskie a konstytucja Cesarstwa}

W historiografii od dawna można znaleźć opinię, że Aleksander, myśląc o wprowadzeniu w Rosji ustroju konstytucyjnego, wykorzystał Królestwo Polskie jako

70 „Il se croyait libéral, parce qu'il ne voulait aucune puissance intermédiaire entre le souverain et un peuple d'esclaves. La noblesse russe lui était odieuse. Loin d'estimer le noble orgueil, qu'inspirait à une famille illustre le souvenir de ses anciens mérites, l'empereur les méprisait, et n'estimait que les distinctions établies par les grades militaires. On le vit appeler à lui, et favoriser particulièrement des gens sans nom et sans état, qui n'avaient que le mérite de leur obscurité, et celui encore d'en sortir, par l'effet d'une volonté toute puissante. L'empereur se souvenait que des noms illustres figuraient parmi ceux des meurtriers de Pierre III et de Paul I. Peut-être ce souvenir fut-il le germe de sa singulière défiance de l'aristocratie. Au couronnement de l'empereur, quelqu'un avait écrit: «Je l'ai vu, précédé des assassins de son grand-père, accompagné de ceux de son père, et suivi, peut-être, des siens». Hélas, cette prédiction a été presque accomplie", R. Rzewuska, Mémoires, ed. G. Caetani Grenier, vol. 2, Rome 1939, s. 9-10.

${ }^{71}$ С.В. Мироненко, Самодержавие и реформы..., с. 189.

72 F.W. Thackeray, Antecedents of Revolution..., s. 57. Hartley cytuje opinię Filipa Wigiela, przyjaciela Puszkina, że Aleksander „miał we krwi miłość do władzy, miarkowaną tylko przez lenistwo i niedbałość" (op. cit., s. 379).

${ }^{73}$ Smolka przypuszcza, że Nowosilcow udostępniał informacje o swojej pracy nie tylko konsulowi pruskiemu, ale także niektórym dygnitarzom w Petersburgu (Nowosilcow..., s. 325).

74 Arakczejew dysponował odpisem zarówno „Précis”, jak i „Gramoty”, К.С. Чернов, Забытая конституция..., с. 17. 
swego rodzaju pole doświadczalne, aby przekonać się, jak system ten funkcjonuje w praktyce ${ }^{75}$. Badacze zajmujący się projektem "Gramoty” uważają to za pewnik. Thackeray nazywa Królestwo „prototypem usprawnionego państwa, które Aleksander zamierzał wprowadzić w Rosji"76. Mironenko widzi w polskiej konstytucji z 1815 r. „preludium, pierwszy akt znacznie szerszego programu” oraz eksperymentalną próbę połączenia systemu konstytucyjnego z samodzierżawiem. Dlatego to car angażował się osobiście w redakcję konstytucji Królestwa i wprowadzenie do niej zabezpieczeń gwarantujących kontrolę monarchy nad organami przedstawicielskimi ${ }^{77}$.

Spojrzenie $\mathrm{z}$ tej perspektywy rzuca nowe światło na rolę Nowosilcowa $\mathrm{w}$ Królestwie Polskim ${ }^{78}$. Eksperyment konstytucyjny, jako szczególnie ryzykowny, musiał być prowadzony pod ścisłą kontrolą. Na jego nadzorcę Aleksander wyznaczył swego „komisarza pełnomocnego” w osobie Nowosilcowa - być może nawiązując przez ten tytuł do Močeniga, który pełnił podobną funkcję przy Republice Siedmiu Wysp. Wybór nie był przypadkowy. Pochodzący z nieprawego związku ${ }^{79}$, pozbawiony dziedzicznego majątku, Nowosilcow nie należał do petersburskiej „oligarchii”. Brak stałych dochodów i wpływowych krewnych na stanowiskach uzależniał go od monarchy - jedynego gwaranta jego kariery. W Komitecie Niejawnym, gdzie zajmował się przede wszystkim sprawami polityki wewnętrznej, nie sprzeciwiał się nigdy opiniom Aleksandra, a podczas dyskusji dotyczących Senatu podkreślał, że rozszerzenie uprawnień tego organu „Związałoby ręce cesarzowi” i przeszkodziło mu przeprowadzić reformy dla dobra narodu ${ }^{80}$. Mimo kilkuletniej niełaski, która dotknęła go w okresie wojen Rosji z napoleońską Francją, potrafił odzyskać względy monarsze i zaprezentować się jako znawca spraw polskich.

75 Zob. A. Barańska, op. cit., s. 62. Podobne funkcje, choć na znacznie mniejszą skalę, mogły pełnić także Wielkie Księstwo Finlandii, Besarabia, a nawet gubernie nadbałtyckie - „testowy” teren dla reform chłopskich.

${ }^{76}$ F.W. Thackeray, Antecedents of Revolution..., s. 147.

77 С.В. Мироненко, Самодержавие и реформы..., с. 154-155. Autor uważa, że „fakt ten nie został doceniony w historiografii”. Askenazy pisze, że Aleksander poprawiał projekt konstytucji Królestwa dwukrotnie. Za pierwszym razem „poczynił [...] niemal przy każdym artykule obszerne własnoręczne uwagi ołówkiem, o charakterze restrykcyjnym, bardzo przewidujące, obliczone na możliwe zostawienie otworów dla samowoli autokratycznej”. Do drugiej redakcji wprowadził już tylko drobne korekty, Sz. Askenazy, Rosja - Polska..., s. 67-68.

78 Opinia Thackeraya, że chociaż osoba Nowosilcowa pojawia się często w literaturze historycznej (zwłaszcza w polskiej, rzadziej w rosyjskiej), to „jego rola w kształtowaniu i kierowaniu polityką w Królestwie Polskim i jego realny wpływ na stosunki polsko-rosyjskie pozostają niejasne" (N.N. Novosil'tsov, the Polish Years, „The Polish Review” 28 (1983), no. 1, s. 33), jest do dziś aktualna. Biografia autorstwa B. Szyndlera (Mikołaj Nowosilcow 1762-1838. Portret carskiego inkwizytora, Warszawa 2004), oparta na literaturze i nielicznych polskich źródłach drukowanych, nic w tej kwestii nie zmieniła.

79 Był synem Marii Stroganowej, która związała się z żonatym mężczyzną; wcześnie osierocony przez matkę, wychowywał się w domu wuja, hr. Aleksandra Siergiejewicza Stroganowa.

80 A. McConnell, op. cit., s. 388. 
Aleksander mógł oczekiwać, że giętki i nieposiadający własnych przekonań politycznych Nowosilcow będzie wobec niego lojalny, a w razie niepowodzenia „eksperymentu" łatwo da się uczynić go kozłem ofiarnym.

W maju 1813 r. Nowosilcow został mianowany wiceprezydentem Rady Najwyższej Tymczasowej Księstwa Warszawskiego (kierowanej przez generał-gubernatora Wasilija Łanskoja). Uczestniczył w dyskusjach nad kolejnymi projektami konstytucji Królestwa Polskiego i opiniował je na użytek Aleksandra ${ }^{81}$. Od 30 sierpnia 1813 r. kierował Komitetem Wyższego Nadzoru Policyjnego. Kiedy w październiku 1815 r. car po drodze z Wiednia do Warszawy zatrzymał się w Berlinie, wezwał do siebie nie Adama Czartoryskiego, ale Nowosilcowa. Ten skorzystał wówczas z okazji, aby zdyskredytować swego kolegę z Komitetu Niejawnego, a potem protektora, pokazując Aleksandrowi kopie listów, jakie książę Adam pisał w sprawie polskiej do polityków brytyjskich ${ }^{82} .1$ grudnia tegoż roku Nowosilcow otrzymał nominację na stanowisko pełnomocnego delegata Jego Cesarskiej Mości przy Radzie Stanu Królestwa Polskiego „na czas pierwszych miesięcy”. Możliwe, że był to okres próbny, podczas którego miał udowodnić swoje kwalifikacje i użyteczność. Nowosilcow przeszedł tę próbę pomyślnie - potwierdzenie tego stanowiła zgoda Aleksandra na jego udział w posiedzeniach Rady Administracyjnej ${ }^{83}$. Stanowisko pełnomocnego komisarza w Warszawie było od początku niekonstytucyjne ${ }^{84}$. Wynikało to $\mathrm{z}$ samej natury jego misji - jako nadzorca eksperymentu musiał stać ponad konstytucją, podobnie jak drugi strażnik interesów monarchy w Królestwie i namiestnik de facto, wielki książę Konstanty ${ }^{85}$. W ten sposób Aleksander mógł praktycznie wypróbować jeszcze jedną ze swych koncepcji - sprawowanie władzy za pośrednictwem dwóch organów lub osób kontrolujących się nawzajem.

Aby dobrze zrozumieć, na czym polegał polityczny eksperyment Aleksandra w Królestwie Polskim, trzeba wziąć pod uwagę wszystkie jego elementy, a nie samą

${ }^{81}$ H. Izdebski, Ustawa konstytucyjna Królestwa Polskiego z 1815 r., w: Konstytucje Polski. Studia monograficzne z dziejów polskiego konstytucjonalizmu, red. M. Kallas, t. 1, Warszawa 1990, s. 192-193, 196-197.

82 S. Smolka, Nowosilcow..., s. 302-306. Podczas wspomnianego pobytu w Berlinie Nowosilcow nawiązał też dobre stosunki z przedstawicielami pruskich kół dyplomatycznych i rządowych.

${ }^{83}$ Nowosilcow osiągnął to za pomocą intrygi. Zasugerował najpierw członkom Rady (za pośrednictwem namiestnika, gen. Zajączka), że car życzy sobie jego obecności w tym gremium, a po uzyskaniu stosownej uchwały rządu, zwrócił się do Aleksandra o aprobatę, S. Smolka, Nowosilcow..., s. 316-318; F.W. Thackeray, Antecedents of Revolution..., s. 29-30.

${ }^{84}$ Historycy amerykańscy widzą w Nowosilcowie carskiego rezydenta na wzór rezydentów napoleońskich w Warszawie (F.W. Thackeray, Antecedents of Revolution..., s. 26) bądź „cywilnego prokonsula”, „super-gubernatora generalnego” o funkcjach nadzorczych (J.P. LeDonne, op. cit., s. 8).

${ }^{85}$ Konstanty bywa określany (zwłaszcza przez polskich historyków) jako „wicekról de facto”. Jest to bezpodstawne, gdyż takiej roli nie odgrywał ani za Aleksandra, ani za Mikołaja. W przekonaniu Rosjan oraz zagranicznych dyplomatów był natomiast od początku namiestnikiem Królestwa, tak też tytułowano go w różnych pismach. 
tylko konstytucję (która, oceniana wedle litery, nie bez racji uważana była za jedną $\mathrm{z}$ najbardziej liberalnych $\mathrm{w}$ ówczesnej Europie) ${ }^{86}$. Ustawa zasadnicza stanowiła bowiem tylko jedną z części składowych szerszego i bardziej złożonego systemu, nad którym pracował rosyjski monarcha. Kluczowe wydają się trzy elementy: pozycja panującego, środki represji i władza „dyskrecjonalna”.

Wykładnię dotyczącą stosunku monarchy do oktrojowanej przez niego konstytucji Aleksander przedstawił w poufnym piśmie wysłanym przez ministra sekretarza stanu Ignacego Sobolewskiego do gen. Józefa Zajączka 16/28 sierpnia 1817 r. Było tam napisane wprost, że „Najjaśniejszy Pan w żadnym wypadku nie uważa dobrodziejstw, którymi obdarzył kraj, za nieodwołalne; uznaje te postanowienia za obowiązujące dla narodu, ale nie dla siebie; $w$ umowie nadanej swoim poddanym, uważa się za sędziego i za stronę, a jej zobowiązań będzie przestrzegał dopóty, dopóki w swojej mądrości osądzi to za odpowiednie dla dobra narodu" ${ }^{87}$. Trudno o jaśniejsze sformułowanie „zasady monarchicznej” i całkowitej suwerenności panującego, stojącego ponad nadanym przez siebie prawem. Warto też zwrócić uwagę, że cytowana deklaracja miała miejsce ponad pół roku przed pierwszym sejmem w Warszawie, zanim doszło do jakichkolwiek nieporozumień z przedstawicielami liberalnej opozycji. Dowodzi to w sposób oczywisty, że Aleksander nigdy nie traktował konstytucji - ani tej, którą nadał Królestwu, ani tej, którą zamierzał wprowadzić w Rosji - za dwustronną umowę między monarchą a jego poddanymi. Miała ona obowiązywać tylko tych ostatnich i mogła zostać w dowolnym momencie odwołana. Inne, późniejsze pismo, odnoszące się do sejmowych „Uwag o raporcie Rady Stanu z działalności rządu” z 1818 r., precyzowało, że prawo „nie upoważnia deputowanych do oskarżania rządu za jego postępowanie, ani do stawiania mu zarzutów, jedynie do wyrażenia opinii na temat materiałów przedłożonych przez rząd sejmowi. [...] Powinno być to przedstawienie jasno sformułowanych pragnień i niezbędnych potrzeb, a nie wykład ogólnych zasad

${ }^{86}$ Analiza treści konstytucji w oderwaniu od praktyki i kontekstu politycznego jest problemem czysto akademickim. Dobrze rozumieli to obywatele Królestwa Polskiego, powtarzający aforyzm Joachima Lelewela, iż za Księstwa Warszawskiego nie było gwarancji wolności osobistej i wolności słowa, ale nikt nie odczuwał ich braku, natomiast za Królestwa były gwarancje, ale nikt nie odczuwał ich istnienia, por. M. Kukiel, Dzieje Polski porozbiorowe 1795-1921, Paryż 1984, s. 174. Ostatnio na problem ten zwrócił uwagę Piotr Pilarczyk w interesującym szkicu o systemie politycznym w Królestwie (System polityczny Królestwa Polskiego 1815-1830. Próba modelu, w: System polityczny..., s. 107-118). Charakteryzuje w nim trafnie formalne i nieformalne ośrodki władzy w Warszawie, jednak ponieważ analizuje tytułowy problem wyłącznie z perspektywy Królestwa i na bazie polskiej literatury, nie wyjaśnia w satysfakcjonujący sposób genezy systemu.

87 „Sa Majesté ne regarde nullement comme irrévocables les bienfaits dont Elle a comblé le pays; Elle croit ses institutions obligatoires pour la nation, mais non pas pour Elle; dans le pacte octroyé à ses sujets, Elle se sent juge et partie, Elle n'en remplira les engagements qu'aussi longtemps que sa sagesse les jugera conformes au bien-être de la nation", D’Angeberg [L. Chodźko], Recueil des traités, conventions et actes diplomatiques concernant la Pologne 1762-1862, Paris 1862, s. 733-734; por. A. Barańska, op. cit., s. 56. 
i teoretycznych rozważań, których błędne zastosowanie doprowadziło świat do tak zgubnych wykroczeń" 88 .

Organiczny składnik systemu konstytucyjnego miały stanowić, w rozumieniu Aleksandra, „proporcjonalne” do swobód środki represji. Po zajęciu ziem Księstwa Warszawskiego przez wojska rosyjskie obok tymczasowej administracji cywilnej zaczął od razu powstawać aparat policyjny organizowany przez Nowosilcowa kierownika Komitetu Wyższego Nadzoru Policyjnego. Po utworzeniu Królestwa rozbudową agend policji, przede wszystkim tajnej, zajmowali się zarówno pełnomocny komisarz, jak i wielki książę Konstanty. Aleksander był zdania, że „obok zasad konstytucyjnych lub liberalnych, które monarcha uważa za stosowne przyjąć dla dobra swego ludu, musi on ustanowić odpowiednie środki represji”. „Uznałem za stosowne nadać Polakom liberalną konstytucję - pisał do ambasadora austriackiego - ale obok tego stworzyłem takie środki represji, aby zrozumieli, że nie mogą jej nadużywać ani przekraczać pewnej granicy. [...] Jestem tu i przy najmniejszym nadużyciu, przy najmniejszym wykroczeniu, daje się odczuć silna ręka władzy" 89 .

Ostatnią, niezwykle istotną kwestią było równoległe funkcjonowanie dwóch struktur władzy: konstytucyjnej (legalnej) i dyskrecjonalnej. Dualizm ten istniał w Królestwie od początku, można nawet zaryzykować twierdzenie, że stanowił konstytutywny element systemu. Władza dyskrecjonalna, reprezentowana przez Konstantego i Nowosilcowa, stała ponad legalną i była podporządkowana Aleksandrowi (jeden z jej atrybutów stanowiło prawo do bezpośredniej korespondencji z monarchą). Podlegała jej tajna policja; kontrolować miała przede wszystkim wojsko, skarb i oświatę.

Wydaje się bardzo prawdopodobne, że Aleksander zaprojektował ustrój Królestwa Polskiego jako prototyp planowanego ustroju Cesarstwa, w którym instytucje konstytucyjne miały współistnieć z pełną autokracją monarchy, kierującego z Petersburga całością państwa i zachowującego całkowitą kontrolę nad poszczególnymi namiestnictwami - tak jak zachowywał ją nad Królestwem.

88 „[Il] n'autorise pas à incriminer les démarches du gouvernement, ni à lui faire des reproches, mais seulement à déclarer l'opinion des députés sur les communications qui seraient faites à la diète. [...] Ce doit être l'expression d'un vœu clair, d'un besoin indispensable et non un exposé des principes généraux et de ces recherches théoriques dont une application erronée entraina le monde dans de si funestes écarts", cyt. za: P. Rain, Alexandre I ${ }^{e r}$. Un tsar idéologue, Paris 1913, s. 311-312, przypis 1 (pismo Sobolewskiego z 23 sierpnia / 4 września 1818 r.); por. A. Barańska, op. cit., s. 64; F.W. Thackeray, Antecedents of Revolution..., s. 52-53.

89 „À côté des principes constitutionnels ou libéraux qu'un souverain croit devoir adopter envers son peuple, il doit établir des moyens de répression proportionnés. J'ai cru devoir donner aux Polonais une constitution libérale; mais j'ai créé à côté des moyens de répression de nature à leur faire connaitre qu'ils ne doivent pas l'abuser ni dépasser une certaine ligne. [...] Je suis là et au moindre excès, à la moindre exagération, le bras fort de l'autorité se fait sentir", cyt. za: P. Rain, op. cit., s. 300-301 (pismo do Louisa Lebzelterna z 10 października 1820 r.); por. A. Barańska, op. cit., s. 56-57. 
Strona polska interpretowała konstytucję i intencje „cesarza i króla” zupełnie inaczej: ustawa zasadnicza była traktowana jako dobrowolna, dwustronna umowa między panującym a obywatelami (zgodnie z piętnowaną przez Konstantego tradycją pacta conventa), a ingerencje wielkiego księcia czy Nowosilcowa w kwestie niewchodzące $\mathrm{w}$ zakres ich oficjalnych kompetencji uznawano za nadużycia, na które należało poskarżyć się monarsze. „Zbyt dosłowne” traktowanie przez Polaków swobód konstytucyjnych doprowadziło po 1820 r. do uruchomienia środków represji, o których Aleksander wspominał austriackiemu dyplomacie, oraz do wzmocnienia i rozszerzenia władzy dyskrecjonalnej. Symboliczny tego wyraz stanowiła carte blanche dla Konstantego na wszystkie działania niezgodne z konstytucją ${ }^{90}$. Zmiana ustroju nie była potrzebna - wystarczyło wykorzystanie mechanizmów funkcjonujących w nim od początku.

Mówiąc o roku 1820, nie można pominąć bardzo istotnego pytania: jeśli Królestwo Polskie było eksperymentem przygotowującym konstytucję rosyjską, co miało się z nim stać po jej ogłoszeniu? Niedatowany projekt ukazu autorstwa Nowosilcowa likwidował odrębność Królestwa i redukował je do jednego z kilkunastu namiestnictw. Takiemu rozwiązaniu trudno odmówić logiki i nie wydaje się, by rację miał Askenazy, widząc w nim jedynie „krecią robotę” pełnomocnego komisarza ${ }^{91}$. Wiernadski jest przekonany, że rozwiązania federalistyczne w „Gramocie” miały na celu przezwyciężenie separatyzmów w „regionach przygranicznych”, a włączenie Polski i Finlandii w strukturę namiestnictw wynikało wprost $\mathrm{z}$ jej pierwszego artykułu ${ }^{92}$. Mironenko i Thackeray uważają, że Nowosilcow przygotował wspomniany projekt nie z własnej inicjatywy, ale na żądanie Aleksandra ${ }^{93}$.

Przeciw powyższej interpretacji przemawiają z kolei wcześniejsze decyzje Aleksandra. Gdyby bowiem od początku zakładał, że po zakończeniu eksperymentu odrębność Królestwa zostanie zlikwidowana, nie nadawałby mu prawdopodobnie tak wyraźnych atrybutów państwowości, zwłaszcza odrębnej armii. Nie czyniłby też swego brata nieformalnym „wielkorządcą" w Warszawie tylko po to, aby odwołać go stamtąd po kilku latach lub zdegradować do stanowiska jednego z kilkunastu namiestników bądź dowódców korpusów. Brak Królestwa Polskiego i Finlandii w wykazie 12 namiestnictw wydaje się dość znamienny ${ }^{94}$. Nie jest on oczywiście dowodem, iż Aleksander zamierzał pozostawić oba te kraje w dotychczasowym

90 F.W. Thackeray, Antecedents of Revolution..., s. 81, 147.

${ }^{11}$ Sz. Askenazy, Rosja - Polska..., s. 188; idem, Łukasiński, t. 1, Warszawa 1929, s. 85-87.

92 „Cesarstwo Rosyjskie ze wszystkimi ziemiami (possessions) przyłączonymi do niego pod jakimkolwiek tytułem bądź nazwą, będzie podzielone na duże rejony zwane namiestnictwami”, G. Vernadsky, op. cit., s. 43 i n., 157 i n.

93 С.В. Мироненко, Самодержавие и реформық.., с. 198; F.W. Thackeray, Antecedents of Revolution..., s. 80-81. Thackeray wiąże to jednak przede wszystkim ze zmianą polityki polskiej Aleksandra, a nie z kwestią „Gramoty”.

94 Chodzi o wykaz znaleziony w papierach Komitetu 6 Grudnia 1826 (zob. przypisy 43 i 44). Dla LeDonne'a fakt, że nie zawierał on Królestwa Polskiego, wystarcza do zakwestionowania jego związku z „Gramotą". Z taką opinią trudno się zgodzić. 
kształcie, ale wskazuje, że nie zakładał z góry scenariusza unifikacji - nawet jeśli go nie wykluczał. Dodatkową komplikację stanowił problem tzw. polskich guberni w Cesarstwie, któremu warto poświęcić nieco więcej uwagi.

\section{Problem „zachodnich guberni”}

W latach 1810-1812, przygotowując się do konfrontacji z Napoleonem, Aleksander rozważał projekt wyodrębnienia z Cesarstwa Wielkiego Księstwa Litewskiego jako osobnej prowincji i konsultował te plany z przedstawicielami orientacji prorosyjskiej na Litwie: Michałem Ogińskim, Ksawerym Druckim-Lubeckim, Ludwikiem Platerem i Kazimierzem Lubomirskim. Kandydatem na stanowisko namiestnika był Georgij Piotrowicz Oldenburg, mąż ulubionej siostry cara, Katarzyny Pawłowny (od 1809 r. generał-gubernator guberni twerskiej, jarosławskiej i nowgorodzkiej). Na początku 1812 r. opracowany został projekt konstytucji „dla Litwy i Polski”, którego autorem był Gustaw Armfeld, przewodniczący komitetu ds. Finlandiii ${ }^{95}$. Dalszy przebieg wydarzeń przekreślił „projekt litewski”, niemniej zajęcie Księstwa Warszawskiego przez Rosjan i perspektywa utworzenia Królestwa Polskiego pod berłem cara postawily na porządku dziennym problem relacji między nowym państwem a ziemiami Rzeczypospolitej wcielonymi do Cesarstwa podczas rozbiorów. Aleksander sugerował przedstawicielom polskiej elity politycznej, że nie wyklucza rozszerzenia Królestwa na wschód. Obietnice te, choć niejasne i ogólnikowe, wzbudziły wielkie oczekiwania po obu stronach Bugu i Niemna. Z punktu widzenia niniejszych rozważań interesujące jest to, że w najbardziej znanych wypowiedziach Aleksandra dotyczących "polskich guberni”: podczas rozmowy z Ogińskim oraz w mowie na otwarcie sejmu w 1818 r., pojawiał się również wątek konstytucji dla Rosji.

Ogiński przybył z upoważnienia cara do Warszawy w listopadzie $1815 \mathrm{r}$. jako delegat szlachty polskiej trzech guberni: wileńskiej, grodzieńskiej i mińskiej. W trakcie prywatnego spotkania Aleksander powiedział mu m.in.: „Utworzyłem to Królestwo, [...] zrobię resztę tak jak obiecałem; lecz to nie może się zrobić od razu. Trzeba zaufania. Winienem wzbudzać takowe po tym, co zrobiłem, a postanowienia moje nie ulegają zmianom" ${ }^{96}$. Poproszony przez Ogińskiego o przyjęcie delegacji litewskiej na oficjalnej audiencji, wyraził zgodę pod warunkiem, że deputowani nie będą poruszać „delikatnej struny”. Padły wówczas słowa:

95 Zob. A. Barańska, op. cit., s. 46-47.

96 „J'ai fait ce royaume, [...] je ferais le reste aussi comme je l'ai promis; mais cela ne peut pas se faire tout d'un coup... Il faut de la confiance. Je dois en inspirer après tout ce que j'ai fait, et mes résolutions ne changent pas". Tekst francuski cytuję według pierwodruku pamiętników: M. Oginski, Mémoires [...] sur la Pologne et les polonais, depuis 1788 jusqu’à la fin de 1815, vol. 4, Paris 1827, s. 233; tekst polski - zgodnie z XIX-wiecznym przekładem: M. Ogiński, Pamiętniki [...] o Polsce i Polakach. Od roku 1788 aż do końca roku 1815, t. 4, Poznań 1873, s. 170. 
Nie mogę przyzwolić, abyście mnie prosili o połączenie waszych prowincji z Polską, ponieważ nie trzeba, aby sądzono, że to wy tego się domagacie. Trzeba, aby było przekonanie, że to wychodzi z mego własnego popędu; że to ja tego pragnę... Wiem, że stosunki, jakie istniały dotychczas między waszymi prowincjami a Rosją, nie mogą wam przypadać do smaku... Nie ma nikogo pomiędzy ludźmi rozsądnymi, co by o tym nie był przekonany. Nie ma nikogo, co by mógł chcieć przypuszczać, że mam zamiar odzyskać [odłączyć] owe prowincje od Rosji... Przeciwnie całkiem, pragnę utwierdzić wpływy [zacieśnić więzy], które je łączą z moim państwem, starając się, aby moi poddani polscy nie mieli powodu uskarżania się... Jesteście niezadowoleni na Litwie i macie powód być nimi tak długo, dopóki nie będziecie zlani w jedną całość z waszymi ziomkami i dopóki nie będziecie korzystać $\mathrm{z}$ dobrodziejstw konstytucji, a wtedy to wasze połączenie $\mathrm{z}$ Rosją utrwali zaufanie i zupełną zgodę między obu narodami. - Powody moje uskutecznienia tego projektu będą jeszcze bardziej uzasadnione, gdy będę miał powód być zadowolnionym na przyszłość, jak nim jestem obecnie, tak z armii, jak ze stanu cywilnego Królestwa. Aż dotąd mam tylko powody chwalić ich... Skoro będę mógł wskazać na rząd ten jako na wzór i skoro spostrzegą, że stąd żadna niedogodność dla Cesarstwa nie wynika, będzie mi rzeczą łatwą uskutecznić resztę. [...] Raz jeszcze, zaufanie i nie narażajcie mnie ${ }^{97}$.

Po audiencji dla litewskich delegatów (26 listopada) car miał powiedzieć do senatora Łanskoja, prezesa Rządu Tymczasowego w Warszawie: „Mają słuszność zawierzając mi i zrobię dla nich więcej nawet, aniżeli się dzisiaj mogą spodziewać”. Łanskoj odebrał to jako zapowiedź przyłączenia Litwy do Królestwa Polskiego; tak też rozumiało słowa Aleksandra wielu Polaków ${ }^{98}$.

W historiografii polskiej relacja Ogińskiego wzmiankowana jest $\mathrm{z}$ reguły w związku z kwestią ziem zabranych, jako przykład niejasnych i nigdy niespełnionych

97 „Je ne puis pas consentir que vous me demandiez la réunion de vos provinces à la Pologne, parce qu'il ne faut pas que l'on s'imagine que c'est vous autres qui le demandez. Il faut que l'on soit persuadé que cela vient de ma propre impulsion; que c'est moi qui le veux... Je sais que les rapports qui ont existé jusqu'à présent entre vos provinces et la Russie ne peuvent vous convenir... Il n'y a personne parmi les hommes raisonnables qui n'en soit convaincu. Il n'y a personne qui puisse admettre la supposition que je veuille détacher ces provinces de la Russie... Tout au contraire, je veux resserrer les liens qui les unissent à mon empire, en faisant que mes sujets polonais n'aient pas raison de se plaindre... Vous êtes mécontents en Lithuanie, et vous devez l'être aussi longtemps que vous ne serez pas amalgamés avec les vôtres, et que vous ne jouirez pas des bienfaits d'une constitution, et c'est alors que votre réunion à la Russie établira une confiance et une concorde parfaite entre les deux nations. Mais raisons pour exécuter ce projet seront encore plus fondées lorsque j'aurai lieu d'être satisfait à l'avenir comme je le suis présentement, et de l'armée, et du civil de ce royaume... Jusqu'à présent, je ne puis que m'en louer... Lorsque je pourrai citer ce gouvernement pour modèle, et qu'on verra qu'il n'en résulte aucun inconvénient pour l'empire, il me sera facile d'effectuer le reste. [...] Encore une fois, de la confiance et ne me compromettez pas", M. Ogiński, Pamiętniki..., s. 171-172; idem, Mémoires..., s. 235-236. Tam gdzie wersja polska odbiega od oryginału, podaję w nawiasach kwadratowych dosłowne tłumaczenie. Interpretując tę relację należy oczywiście brać pod uwagę, że jej autor przytacza cały dyskurs Aleksandra z pamięci.

98 M. Ogiński, Pamiętniki..., s. 176 (por. idem, Mémoires..., s. 242); K. Bartoszewicz, Utworzenie Królestwa Kongresowego, Kraków 1916, s. 195-198. 
obietnic cara dotyczących ich połączenia z Królestwem. Inaczej - i zapewne trafniej - interpretuje ją Thackeray, zdaniem którego Aleksander poinformował swego rozmówcę, że nie oderwie zachodnich guberni od Cesarstwa, natomiast planuje unię wszystkich Polaków z Rosją w ramach wspólnego, federalnego państwa konstytucyjnego. „Nigdy też - jak dodaje tenże historyk - nie określił jaśniej swej polityki wobec Litwy" 99 . Także Mironenko nie ma żadnych wątpliwości, że zapowiedzi cara dotyczyły wprowadzenia ustroju konstytucyjnego w całym Imperium oraz rozwiązania problemu guberni litewsko-ruskich przez nadanie ich mieszkańcom tych samych praw, jakie w 1815 r. otrzymali Polacy w Królestwie ${ }^{100}$.

Oba tematy powróciły w głośnej mowie Aleksandra na otwarcie pierwszego sejmu w Warszawie. W przeciwieństwie do rozmów z Polakami zza Niemna, które odbywały się nieformalnie i bez rozgłosu, tym razem chodziło o wystąpienie publiczne, obserwowane i komentowane zarówno w Petersburgu, jak i w stolicach Europy. Aleksander, co podkreślają wszyscy biografowie, przygotowywał swoje exposé długo i starannie. Konsultował jego treść z Capodistriasem i kilkoma innymi osobami, ostatecznie jednak nie uwzględnił żadnych krytycznych uwag i pozostał przy własnej wersji. Zawierała ona deklaracje podobne do tych, które usłyszał Ogiński, chociaż wyrażone w znacznie bardziej zawoalowany sposób:

Reprezentanci Królestwa Polskiego! Spełniają się wasze nadzieje i moje życzenia. [...] Organizacja trwająca w waszym kraju dozwalała niezwłocznego ustanowienia tej, jaką wam nadałem, wprowadzając $\mathrm{w}$ wykonanie prawidła ustaw liberalnych, które nie przestawały nigdy zajmować całej mej troskliwości, a których spodziewam się przy pomocy Boskiej rozciągnąć wpływ zbawienny na wszystkie krainy, jakie od Opatrzności mej pieczy są poruczone. Podaliście mi przeto sposobność okazania mej ojczyźnie tego, co dla niej od dawna gotuję i co otrzyma, skoro zarody tak ważnego dzieła będą mogły dosięgnąć potrzebnego rozwinięcia. [...] Skutki prac waszych w tym pierwszym zgromadzeniu nauczą mnie, czego w przyszłości ojczyzna może oczekiwać po waszym dla niej poświęceniu się, jako też po waszych dobrych ku mnie uczuciach, i czyli, wierny moim przedsięwzięciom, będę mógł dalej rozszerzyć to, co już dla was uczyniłem ${ }^{101}$.

99 F.W. Thackeray, Antecedents of Revolution..., s. 42.

100 С.В. Мироненко, Самодержавие и реформы..., с. 154.

101 „Representants du Royaume de Pologne! Vos esperances et mes voeux s'accomplissent. [...] L'organisation qui était en vigueur dans votre pays a permis l'établissement immédiat de celle que je vous ai donnée, en mettant en pratique les principes de ces institutions libérales qui n'ont cessé de faire l'objet de ma sollicitude, et dont j'espère avec l'aide de Dieu étendre l'influence salutaire sur toutes les contrées que la Providence a confiées à mes soins. Vous m'avez ainsi offert les moyens de montrer à ma patrie ce que je prépare pour elle dès longtemps, et ce qu'elle obtiendra, lorsque les éléments d'une œuvre aussi important auront atteint le développement nécessaire. [...] Les résultats de vos travaux dans cette première assemblée, m’apprendront ce que la patrie doit attendre à l'avenir de votre dévouement pour elle, comme de vos bon sentiments pour moi, et si, fidèle à mes résolutions je puis étendre ce que j’ai déjà fait pour vous”. Cytuję według wersji z „Gazety Warszawskiej”, dodatek do nr 25 z 28 III 1818, s. 637-641 (pełny tekst w języku francuskim i urzędowym przekładzie polskim). 
Na polecenie cara tekst został od razu przetłumaczony na rosyjski i opublikowany w Cesarstwie ${ }^{102}$.

Polscy słuchacze mowy Aleksandra, a w późniejszym czasie polscy historycy, u których kwestia ewentualnych reform w Rosji budziła znacznie mniejsze zainteresowanie niż sprawy ojczyzny, odnosili jej zakończenie do rozszerzenia Królestwa o ziemie zabrane ${ }^{103}$. Z ujęciem tym polemizuje zdecydowanie Mironenko. Uważa on, że przemówienie nie daje żadnych podstaw do takiej interpretacji i że pojawiła się ona dopiero w opracowaniach niektórych badaczy odwołujących się do niepublikowanych wspomnień Capodistriasa ${ }^{104}$. Odczytując tekst literalnie, wypadałoby przyznać rację rosyjskiemu historykowi, jednak ograniczenie się do takiej lektury nie wydaje się w tym wypadku właściwe. Capodistrias - do czego zresztą nawiązuje Mironenko - radził (bezskutecznie) carowi usunąć z mowy dwa punkty: porównanie Polski z Rosją i „obietnicę przyłączenia do Królestwa Polskiego guberni wchodzących w skład Cesarstwa"105. Jeśli minister spraw zagranicznych i długoletni współpracownik Aleksandra $\mathrm{w}$ ten sposób rozumiał jego słowa i czuł się nimi na tyle zaniepokojony, że odważył się na otwartą krytykę, można przypuszczać, że podobnie odbierały je także inne osoby. Pogłoski o planowanym połączeniu obu "polskich prowincji” krążyły w Rosji od czasu kongresu wiedeńskiego, a do ich wzmocnienia przyczyniły się konkretne kroki Aleksandra: faktyczne spolszczenie administracji w pięciu guberniach zachodnich (wileńskiej, grodzieńskiej, mińskiej, wołyńskiej oraz podolskiej) ${ }^{106}$ oraz wyodrębnienie Korpusu Litewskiego z armii Cesarstwa i oddanie go pod komendę wielkiego księcia Konstantego w 1817 r. Retoryczne pytanie postawione przez Karamzina w 1819 r.: „Czy Wasza Cesarska Mość może z czystym sumieniem odebrać nam Białoruś, Litwę, Wołyń, Podole?”107, wyraźnie świadczy o napięciu, z jakim rosyjskie elity obserwowały polską politykę swego monarchy.

102 Wystąpieniu Aleksandra na sejmie w Warszawie nadano wyjątkowy rozgłos. Zazwyczaj społeczeństwo rosyjskie było bardzo słabo informowane o konstytucyjnej praktyce i życiu politycznym w Królestwie Polskim, Н.М. Филатова, Русское общество и Королевство Польское в 1815-1830 г2., w: Польша и Россия в первой трети ХІХ века. Из истории автономного Королевства Польского 1815-1830, Москва 2010, с. 479.

103 S. Cieszkowski, op. cit., s. 84-85; Sz. Askenazy, Łukasiński..., t. 1, s. 80-81.

104 С.В. Мироненко, Самодержавие и реформы..., с. 158. Autor wymienia w tym miejscu Askenazego i zarzuca mu arbitralne połączenie w całość kilku różnych fragmentów przemówienia oraz zacytowanie ich we własnym przekładzie, różniącym się od polskiej wersji urzędowej. O ile pierwszy zarzut można uznać za uzasadniony, trudno zgodzić się z drugim - zmiany translatorskie dokonane przez Askenazego nie są istotne, ponadto spory o przekład wydają się jałowe w sytuacji, kiedy można odnieść się do oryginalnej wersji francuskiej napisanej i wygłoszonej przez samego Aleksandra.

105 Ibidem, c. 155 i n.

106 Pozostałe trzy gubernie należące do ziem zabranych: witebska, mohylewska i kijowska były konsekwentnie traktowane przez Aleksandra jako rosyjskie.

107 Cyt. za: P. Rain, op. cit., s. 290. 
Czernow uważa, że mowa Aleksandra na sejmie 1818 r. była przede wszystkim testem dla rosyjskiej opinii publicznej. Car, jak to miał w zwyczaju, posłużył się językiem wieloznacznym i aluzyjnym, który mógł być różnie interpretowany - w ten sposób nie wiązał sobie rąk, a jednocześnie prowokował Rosjan do ujawnienia ich punktu widzenia. Według autora monografii o "Gramocie” francuski termin étendre („rozszerzać”) mógł sugerować zarówno rozszerzenie granic Królestwa Polskiego, jak i zwiększenie swobód konstytucyjnych ${ }^{108}$. Reakcja, jak wiadomo, była generalnie nieprzychylna. Rosyjska szlachta poczuła się głęboko zaniepokojona perspektywą ewentualnych reform dotyczących wsi i stosunków poddańczych, zapowiedź rozszerzenia „liberalnych ustaw” została odebrana pozytywnie tylko w wąskich kręgach młodych opozycjonistów, a wszystkie odłamy opinii zjednoczyła irytacja wywołana "polonofilstwem” monarchy ${ }^{109}$. Możliwe, że całkowite utajnienie prac nad projektem rosyjskiej konstytucji oraz pominięcie w niej sprawy chłopskiej były konsekwencją tak znacznego sprzeciwu.

Wielu historyków, poczynając od Szyldera i Smolki, a kończąc na Thackerayu, Donnercie i Pisarkowej, uważa, że Aleksander rzeczywiście zamierzał połączyć część guberni zachodnich z Królestwem Polskim. Donnert, którego trudno podejrzewać o tendencyjne, "propolskie” interpretacje, jest zdania, że w 1818 r. car zrezygnował $\mathrm{z}$ „wypełnienia swojej obietnicy” ze względu na opozycję ze strony rosyjskich nacjonalistów. W ten sposób ziemie litewsko-ruskie - „zona buforowa między Polską a Rosją" - stały się jedną z głównych trudności na drodze do „federalistycznej restrukturyzacji” Imperium ${ }^{110}$. Pisarkowa cytuje twardą odprawę, z jaką spotkała się pewna dama, która błagała Aleksandra, by nie odbierał Rosji guberni zachodnich, i wyraża opinię, że do zachowania tej prowincji w granicach Cesarstwa przyczynił się przede wszystkim Karamzin ${ }^{111}$.

Podczas gdy w kancelarii Nowosilcowa trwały prace nad pierwszą redakcją rosyjskiej konstytucji, Aleksander ukazem z 19 czerwca 1819 r. nadał „głównodowodzącemu Korpusem Litewskim JCW Cesarzewiczowi Konstantemu” władzę naczelnego dowódcy armii czynnej w pięciu guberniach zachodnich. Nominacja ta dawała wielkiemu księciu prawo „reprezentowania osoby Monarchy” i sprawowania

108 К.С. Чернов, Забытая конституиця..., с. 43-44. Przypuszczenie, że Aleksander chciał wysondować opinię, wygłaszając "prowokujące, choć niezobowiązujące deklaracje”, wyraził wcześniej F.W. Thackeray, Antecedents of Revolution..., s. 47.

109 A. Barańska, op. cit., s. 58-59. Do podsycenia antypolskich nastrojów przyczynił się Wiaziemski, który w rosyjskim przekładzie mowy przetłumaczył słowo organisation, odnoszące się do ustroju i administracji na ziemiach byłego Księstwa Warszawskiego, przez образование (wykształcenie), co sugerowało, że w porównaniu z Polakami społeczeństwo rosyjskie jest mniej oświecone, F.W. Thackeray, Antecedents of Revolution..., s. 48.

110 Э. Доннерт, op. cit., с. 207.

111 Л.Ф. Писарькова, ор. cit., с. 307. Car miał powiedzieć: „Także tego nie pozostawię Rosji. I, ostatecznie, co Pani widzi złego w tym oderwaniu? Czy Rosja nie jest dostatecznie wielka i bez tych guberni?" 
„władzy cesarskiej”. Konstanty przejął także wówczas faktyczny nadzór nad administracją cywilną na tym terenie ${ }^{112}$. Przy okazji dyskusji nad „Précis” w październiku tegoż roku car polecił Nowosilcowowi przygotowanie przekładu aktów unii Polski z Litwą z 1413 i 1501 r. W komentarzu dołączonym do tłumaczenia komisarz pełnomocny podkreślił szczególnie ujednolicenie administracji w obu krajach oraz to, że zwierzchnictwo nad Litwą sprawował de iure król Polski, natomiast de facto - jego brat ${ }^{113}$. Szylder wiąże te fakty z myślą Aleksandra o „odbudowaniu Polski w jej wcześniejszych granicach, oczywiście tylko ze strony wschodniej”, który to pomysł został później odłożony (ale nie odrzucony) z powodu „powszechnego niezadowolenia, które okazywali wobec niego w Rosji ludzie o skrajnie różnych poglądach politycznych"114. Nasuwa się jednak pytanie, czy zainteresowanie cara traktatami z epoki jagiellońskiej nie wiązało się raczej z ideą unii między rozszerzonym Królestwem Polskim a Rosją. Rola Władysława Jagiełły przypadałaby w tym układzie Aleksandrowi, a Witolda - Konstantemu, natomiast ujednolicenie administracji zostałoby osiągnięte przez wprowadzenie „Gramoty”. Decyzje Aleksandra z lat 1817-1819 dotyczące guberni zachodnich wskazują, że mógł w tym czasie rozważać i taki scenariusz. Przypuszczenie Thackeraya, że „eksperyment konstytucyjny" miał być rozciągnięty w pierwszej kolejności na ziemie litewsko-ruskie, a dopiero później na całe Cesarstwo ${ }^{115}$, jest mało prawdopodobne, bowiem taka taktyka mogła jedynie utrudnić całą operację.

Na problem ziem zabranych warto spojrzeć także z perspektywy polityki narodowościowej Aleksandra. Analizując przypadek Finlandii, Donnert dochodzi do wniosku, że car nadał temu narodowi, nieuznawanemu przez Szwedów, odrębny byt, ponieważ „szczerze wierzył w prawo narodów do istnienia i niezależności oraz był rzeczywiście przeświadczony, że narodowa niezawisłość jest możliwa w sojuszu z Rosją i pod jej władzą". Wiązało się to z ogólniejszą ideą, wedle której jedyną drogę do pokoju w Cesarstwie Rosyjskim, jak też w całej Europie, miała stanowić „przyjaźń narodów, żyjących w warunkach mądrze ograniczonej wolności”116. W koncepcji tej nietrudno zauważyć echo teorii Adama Czartoryskiego o reformie stosunków międzynarodowych, rozwiązaniu problemu konfliktów zbrojnych

112 E.P. Karnowicz, Wielki książe Konstanty. Zarys biograficzny, tłum. z ros., Warszawa 1900, s. 28-29. Autor cytowanego opracowania komentował to w następujący sposób: „Sytuacja tych prowincji była teraz nadzwyczaj dziwaczna: będąc pod zarządem głównodowodzącego armią czynną, znajdowały się niejako w stanie wojennym, a jednocześnie, będąc pod władzą osoby, która także zarządzała Królestwem Polskim, były one niejako pod względem administracyjnym złączone $\mathrm{z}$ tym ostatnim, do czego tak gorliwie dążyli patrioci polscy [...]. Z drugiej jednak strony, sam charakter tego złączenia był środkiem surowym, do którego uciekano się tylko w wypadkach nadzwyczajnych", ibidem.

113 F.W. Thackeray, Antecedents of Revolution..., s. 59.

114 Н.К. Шильдер, ор. cit., т. 4, с. 173. Podobnie sądzi Thackeray (zob. wyżej).

115 F.W. Thackeray, Antecedents of Revolution..., s. 44.

116 Э. Доннерт, op. cit., с. 195-196. 
i połączeniu zasady suwerenności narodowej z systemem federacyjnym ${ }^{117}$. W pierwszych latach panowania Aleksandra książę Adam żywił nadzieję, że młody imperator przyczyni się do przebudowania w tym duchu całej Europy. Autonomia Finlandii i Polski w granicach Cesarstwa Rosyjskiego wyraźnie nawiązywała do owego programu. Nie można więc wykluczyć, że car rozważał stworzenie dwóch kategorii namiestnictw: rosyjskich oraz wyodrębnionych wedle kryterium narodowościowego (jak Finlandia czy Polska rozszerzona o gubernie zachodnie). Te drugie mogłyby wówczas zachować, na wzór Węgier czy Lombardii-Wenecji w monarchii habsburskiej, swój odrębny status, podkreślony dodatkowo przez powierzenie stanowiska namiestnika młodszym członkom dynastii. Niemniej wiele wskazuje na to, że w 1820 r. Aleksander zaczął się skłaniać do łatwiejszego rozwiązania - utworzenia $\mathrm{z}$ pięciu guberni zachodnich osobnego namiestnictwa ze stolicą $\mathrm{w}$ Wilnie (w wykazie namiestnictw znalazło się ono na ostatnim, dwunastym miejscu) ${ }^{118}$.

\section{Podzwonne projektu z $1820 \mathrm{r}$.}

Kryzys polityczny lat 1820-1821 w Królestwie Polskim zbiegł się porzuceniem (czy też, jak chcą niektórzy badacze, odroczeniem) przez Aleksandra planu reformy ustrojowej w Cesarstwie. Nie wchodząc w szczegóły dyskusji o przyczynach reorientacji polityki rosyjskiego monarchy ${ }^{119}$, trzeba powtórzyć $\mathrm{w}$ tym miejscu to, o czym dobrze wiedziały dyplomacja austriacka i pruska - wprowadzenie "Gramoty" w życie było w ówczesnych warunkach niemożliwe. Na etapie opracowywania teoretycznych założeń projektu Aleksander mógł bagatelizować problemy związane $\mathrm{z}$ jego urzeczywistnieniem, kiedy jednak konstytucja była gotowa, nie miał w gruncie rzeczy innego wyjścia niż pozostawienie jej w zaciszu kancelarii

117 Czartoryski przedstawił ją w sposób systematyczny w Essai sur la diplomatie wydanym w 1830 r., ale najważniejsze założenia sformułował dużo wcześniej, kiedy kierował resortem spraw zagranicznych Cesarstwa Rosyjskiego, zob. A. Czartoryski, Rozważania o dyplomacji, tłum. J.M. Kłoczowski, oprac. M. Kornat, Kraków 2011 i M. Kornat, Reforma dyplomacji i legitymizm narodów. Adam Jerzy Czartoryski i jego „Rozważania o dyplomacji”, w: A. Czartoryski, op. cit., s. 347-602.

118 Interesujący szczegół potwierdzający wahania cara można znaleźć w tabeli opracowanej przez Czernowa. Zestawił on stolice namiestnictw i nazwiska planowanych namiestników (ustalone na podstawie archiwaliów) z nazwiskami rzeczywistych generał-gubernatorów z $1825 \mathrm{r}$. Jedynie dla Wilna nie przewidziano żadnego namiestnika; generał-gubernatorem był tam Aleksander Michajłowicz Rimski-Korsakow, podlegający od 1819 r. wielkiemu księciu Konstantemu, K.С. Чернов, Забытая конституция..., приложение 4-2, с. 149-151.

119 Na uwagę zasługuje opinia Donnerta, że najbardziej zaniepokoił Aleksandra bunt w Siemionowskim Pułku Gwardii w październiku 1820 r. (op. cit., s. 208). Jednostka ta, złożona z elitarnej młodzieży, znajdowała się wcześniej pod jego bezpośrednią komendą. W buncie gwardzistów (w rzeczywistości spowodowanym przez konflikt oficerów z nowym dowódcą, despotą i okrutnikiem) car mógł widzieć zarówno efekt przenikania do Rosji ideologii rewolucyjnych, jak i widmo spisku dworskiego. Jedno i drugie nakazywało wycofanie się z niebezpiecznej drogi reformy. 
Nowosilcowa. Alternatywą mógł być tylko odgórny zamach stanu, ale osobowość i charakter cara wykluczały taki sposób działania. Ponadto nie dysponował on żadną oddaną sobie grupą ludzi, którzy mogliby wesprzeć przewrót, a potem objąć kluczowe stanowiska w stolicy i na prowincji. Smolka sugeruje, że to Arakczejew, odpowiedzialny za bezpieczeństwo Aleksandra, uświadomił mu, jak wielkie ryzyko wiązałoby się z kontynuowaniem projektu, i „zmusił go rzucić w kosz konstytucję i połączenie Litwy z Królestwem” oraz zagwarantować elicie politycznej, że "nie powtórzy się nigdy zamach na parcelację samodzierżawia" ${ }^{20}$. Jednak i bez tego Aleksander był zbyt doświadczonym politykiem, aby nie zorientować się, że w sprawie „Gramoty” nie tylko nie może liczyć na żadne poparcie, ale zjednoczyłby przeciw sobie wszystkie siły polityczne: petersburskich dygnitarzy i senatorów zagrożonych utratą wpływów, prowincjonalną szlachtę obawiającą się naruszenia stosunków poddańczych, wielkorosyjskich patriotów przeciwnych autonomii regionów, a jednocześnie Polaków i Finów zaniepokojonych perspektywą utraty dotychczasowego statusu w Imperium. Możliwe, że pod wpływem wydarzeń w Europie uznał też, że jego władzy zagraża nie tylko arystokratyczna oligarchia, ale i międzynarodowa „hydra rewolucji”.

Zdaniem Mironenki Aleksander, zmuszony do rezygnacji ze swoich zamiarów ze względu na zdecydowany opór przeważającej części rosyjskiej klasy politycznej, nie potrafił przyznać się sam przed sobą do całkowitej porażki i pozorował wobec otoczenia dalszą pracę nad przygotowaniem reform. To właśnie miało być przyczyną ciężkiego kryzysu psychicznego, który uwidocznił się w ostatnich latach jego panowania ${ }^{121}$. Kwestia, czy po 1820 r. car definitywnie wyrzekł się wcześniejszych projektów, czy też podejmował nadal pewne ostrożne i ukryte działania, pozostaje przedmiotem sporu wśród historyków. Wśród inicjatyw związanych genetycznie z "Gramotą" wymienia się przede wszystkim misję gen. Bałaszowa, który w listopadzie 1819 r. został zwolniony ze stanowiska ministra policji i mianowany generał-gubernatorem pięciu guberni w centralnej Rosji (tulskiej, orłowskiej, woroneżskiej, tambowskiej i riazańskiej) ${ }^{122}$. Wiernadski dowodzi, że Aleksander pragnął w ten sposób wypracować model funkcjonowania namiestnictwa ${ }^{123}$. Bałaszow nie został poinformowany o pracach nad konstytucją, wiedział jedynie, że car zamierza zreformować administrację wewnętrzną, opierając ją na fundamencie prawa; że $\mathrm{w}$ tym celu organizuje regiony obejmujące po kilka guberni pod kontrolą generał-gubernatorów; że powierza mu zorganizowanie pierwszego z nich; że w dalszej

120 S. Smolka, Nowosilcow..., s. 326-327.

121 С.В. Мироненко, Страницы тайной истории.., с. 73.

122 Obszar ten odpowiadał siódmemu namiestnictwu z wykazu znalezionego w papierach Komitetu 6 Grudnia 1826.

${ }^{123}$ G. Vernadsky, op. cit., s. 46-54. Wcześniej, jako minister, Bałaszow nie zajmował się bieżącymi sprawami resortu, ale generalną organizacją systemu policyjnego w Cesarstwie. Aleksander powierzał mu również pewne misje specjalne, ibidem, s. 51. Zob. też: С.В. Мироненко, Самодержавие и реформы..., с. 178-181. 
kolejności planuje podział całego państwa na takie regiony, z dopuszczeniem pewnych modyfikacji stosownie do warunków lokalnych ${ }^{124}$. Nominacja nie precyzowała jego kompetencji, nie otrzymał też instrukcji na piśmie - miał się kontaktować bezpośrednio z monarchą. Wiosną $1823 \mathrm{r}$. Aleksander polecił mu zreformować administrację w jednej tylko guberni (riazańskiej) i nadał prawo do mianowania urzędników oraz tworzenia nowych stanowisk. Bałaszow miał również powołać „radę gubernialną". Projekt organizacji rad gubernialnych i obwodowych przedłożył carowi w styczniu 1825 r. ${ }^{125}$ Kulisów nominacji Bałaszowa domyślali się niektórzy przeciwnicy konstytucyjnych planów Aleksandra. W 1826 r. został on anonimowo oskarżony przed Mikołajem I o tworzenie nowych instytucji, które „pod pozorem rad, wprowadzają zasady konstytucyjne"126. W 1829 r. gen. Iwan Dybicz tłumaczył Aleksandrowi Michajłowskiemu-Danilewskiemu, że „car Aleksander chciał poprzez powołanie generał-gubernatorów wprowadzić rządy konstytucyjne, zaczynając od tego, aby w każdym generalnym gubernatorstwie istniała Rada złożona z kilku deputowanych"127.

O ile charakter misji Bałaszowa pozostaje kwestią dyskusyjną ${ }^{128}$, o tyle żadnych wątpliwości nie budzi ścisły związek między „Gramotą” a zachowanym w kancelarii Nowosilcowa francuskim rękopisem zatytułowanym „Tableau sommaire des matières qui entreront dans les livres II et III du projet de règlement organique" („Zbiorczy spis zagadnień, które wejdą do II i III księgi statutu organicznego”) ${ }^{129}$. Księgi te miały dotyczyć administracji i sądownictwa; spis obejmuje planowane tytuły, rozdziały i sekcje, a kończy się deklaracją monarchy, który zobowiązuje się do przestrzegania ich postanowień i, podobnie jak w zakończeniu "Gramoty", wyraża pragnienie zapewnienia wszystkim swoim poddanym dobrobytu, nietykalności osób i majątków, zachowania praw cywilnych i politycznych oraz (czego nie było w "Gramocie”) „niezależności społecznej” (indépendance sociale). Wiernadski uważa „Tableau sommaire” za fragment nowej, trzeciej (po wersji z 1819 i 1820) redakcji rosyjskiej konstytucji ${ }^{130}$, Mironenko - za ciąg dalszy

124 G. Vernadsky, op. cit., s. 48-49.

125 Ibidem, s. 52-54, 86-87; С.В. Мироненко, Самодержавие и реформы..., с. 200-202. W ograniczeniu reformy do terenu jednej guberni Mironenko widzi dowód rezygnacji cara $\mathrm{z}$ wprowadzenia „Gramoty”.

126 G. Vernadsky, op. cit., s. 50. W efekcie Bałaszow musiał tłumaczyć się ze swoich zarządzeń przed Komitetem 6 Grudnia 1826. Mikołaj nakazał mu przywrócenie administracji do poprzedniego stanu, ibidem, s. 56-61.

127 Суt. za: С.В. Мироненко, Самодержавие и реформыл.., с. 178.

128 Jej powiązanie z projektem konstytucji z 1820 r. kwestionuje np. J.P. LeDonne, op. cit., s. 15, przypis 23 .

129 Tekst został opublikowany najpierw w warszawskiej edycji „Gramoty” z 1831 r., a następnie przez Schiemanna w 1903 r. (zob. przypis 34).

130 G. Vernadsky, op. cit., s. 86-90. Autor podkreśla, że w porównaniu z „Gramotą” system administracyjny jest tu bardziej scentralizowany, brakuje wzmianek o sejmach, natomiast pojawia się aluzja do zmiany systemu poddaństwa chłopów (gwarancja „niezależności społecznej”). 
„Gramoty”, opracowany po przeniesieniu prac z Warszawy do Petersburga ${ }^{131}$. Również w kwestii datowania rękopisu występują różnice zdań: według Mironenki powstał on w $1821 \mathrm{r}$. lub nieco później ${ }^{132}$, według Czernowa - nie wcześniej niż wiosną-latem $1824 \mathrm{r}^{133}$, według Wiernadskiego - w 1824 r. ${ }^{134}$

Związek kryzysu w Królestwie Polskim ze sprawą „Gramoty” był bardzo złożony. Rezygnacja Aleksandra $\mathrm{z}$ reformy usuwała wprawdzie niebezpieczeństwo przemianowania Królestwa na namiestnictwo, ale stawiała pod znakiem zapytania potrzebę dalszego utrzymywania konstytucyjnego „laboratorium”. Nowosilcow natychmiast dostosował się do nowej orientacji i w raporcie o stanie państwa z 24 maja $1821 \mathrm{r}$. doniósł, że skarb jest bliski bankructwa, a kraj stał się terenem działania tajnych organizacji, demagogów i burzycieli porządku publicznego. Niedługo potem doszło do znanego oświadczenia Aleksandra, że jeśli Królestwo Polskie nie osiągnie równowagi finansowej pozwalającej „wydołać z własnych funduszów politycznemu i cywilnemu bytowi, którym zostało obdarzone”, może „ulec zaprowadzeniu porządku rzeczy więcej zastosowanemu do swych sił szczupłości” ${ }^{135}$. Ostatecznie, jak wspomniano wyżej, kryzys zakończył się ograniczeniem realnych kompetencji organów konstytucyjnych na rzecz władzy dyskrecjonalnej. Zdaniem Marcelego Handelsmana struktura tej ostatniej została wówczas zmodyfikowana: obok Konstantego i Nowosilcowa pojawił się Drucki-Lubecki, który przejął kontrolę nad gospodarką i finansami Królestwa ${ }^{136}$. Pozycja księcia-ministra była w tym gronie niewątpliwie najsłabsza, niemniej i on otrzymał nieformalny przywilej bezpośredniej korespondencji z monarchą. Walka o wpływ na sprawy wewnętrzne między Nowosilcowem a Lubeckim, do której wkrótce doszło, dawała Aleksandrowi nowe możliwości sterowania sceną polityczną w Królestwie.

Kwestia ziem litewsko-ruskich zaczęła się w tym czasie łączyć ze sprawą sukcesji tronu. Ukaz z lipca 1822 r., który potwierdził i uprawomocnił władzę cywilną i wojskową Konstantego na terenie pięciu guberni zachodnich, był - zdaniem

131 С.В. Мироненко, Самодержавие и реформы..., с. 199. „Gramota” stanowiłaby w tym układzie księgę I, „statut organiczny” - księgę II i III. Na to, że projekt został zredagowany w Petersburgu, wskazuje - zdaniem Mironenki - końcowa formuła „wydano w Naszym Pałacu Zimowym...” (daty i podpisu brak). Argument ten nie wydaje się jednak rozstrzygający, tym bardziej że rękopis został znaleziony razem z „Gramotą” w warszawskiej kancelarii Nowosilcowa.

132 Ibidem, c. 200. Autor podkreśla związek „Tableau sommaire” $\mathrm{z}$ „Projektem ustanowienia namiestnictw” z 1821 r., który opiniował i uzupełniał Sperański, wezwany w tym czasie z Syberii do Petersburga i mianowany członkiem Rady Państwa.

133 К.С. Чернов, Забытая конституция..., с. 51.

134 G. Vernadsky, op. cit., s. 87. Zgodnie z tą hipotezą „Tableau sommaire” byłby związany z konferencją generał-gubernatorów wiosną 1824 r. i eksperymentami Bałaszowa z przełomu 1824 i $1825 \mathrm{r}$.

135 M. Handelsman, Kryzys r. 1821 w Królestwie Polskim, „Kwartalnik Historyczny” 53 (1939), nr 2, s. 243; A. Barańska, op. cit., s. 60.

${ }^{136}$ M. Handelsman, op. cit., s. 247. W gestii Nowosilcowa pozostały szkolnictwo i kultura. 
Askenazego - rekompensatą za jego rezygnację z korony cesarskiej ${ }^{137}$. Jednak domniemane aspiracje wielkiego księcia do "polsko-litewskiego wielkorządztwa” i wykorzystanie ich przez Aleksandra w rozgrywce dynastycznej nie miały bezpośredniego związku z projektem konstytucyjnym.

Niektórzy historycy uważają, że Aleksander do końca swego panowania nie wyrzekł się zamiaru reformy Cesarstwa, jeśli nie konstytucyjnej, to przynajmniej administracyjnej. Powołują się przy tym zarówno na działalność Bałaszowa, innych generał-gubernatorów czy projekty dotyczące namiestnictw, jak i na wypowiedzi cara z 1825 r., zwłaszcza z okresu pobytu w Warszawie z okazji trzeciego sejmu w Królestwie ${ }^{138}$. Najdalej pod tym względem idzie Czernow, stwierdzając, że do całościowego opracowania reformy brakowało już tylko modelu lokalnych instytucji policyjnych i sądowych, i że jej wprowadzeniu w życie przeszkodziła wyłącznie przedwczesna śmierć Aleksandra ${ }^{139}$. Ta ostatnia teza opiera się jednak na błędnym założeniu, że planowana restrukturyzacja Cesarstwa nie naruszała interesów petersburskiej arystokracji i że Aleksander nie napotkałby z jej strony większego oporu ${ }^{140}$.

Według Askenazego projekt rosyjskiej konstytucji miał pierwotnie stanowić „spółczynnik dopełniający i ułatwiający postępowe i restytucyjne zamiary Aleksandra względem Polski” ${ }^{141}$. W rzeczywistości było odwrotnie - to sprawa polska co najmniej od czasu kongresu wiedeńskiego podporządkowana została sprawie reformy Cesarstwa. Obecność w Warszawie Nowosilcowa (którego car mógł w razie potrzeby wymienić na inną osobę) nie była ani przypadkiem, ani „błędem w sztuce”, ale niezbędnym elementem politycznego eksperymentu, który wymagał stałego nadzorcy i analityka. To, że pełnomocny komisarz, człowiek sprzedajny i cyniczny, nie zachowywał się lojalnie wobec swego mocodawcy, stanowiło zupełnie inną kwestię.

Analiza projektu z 1820 r. wyłącznie w aspekcie historii idei i rozwoju konstytucjonalizmu, choć sama w sobie ciekawa, może doprowadzić do całkowicie błędnych wniosków, ponieważ rosyjski monarcha interpretował kluczowe terminy i koncepcje inaczej niż ich zachodnioeuropejscy twórcy. „Eksperymentalne” Królestwo Polskie dostarcza na to wielu dowodów. Aleksander testował nie tylko polską konstytucję z 1815 r., której był współautorem, ale cały „hybrydowy” system w Królestwie, polegający na połączeniu rządów konstytucyjnych z autokracją

\footnotetext{
Sz. Askenazy, Łukasiński..., t. 1, s. 166-167 i n.

138 S. Smolka, Polityka Lubeckiego..., t. 1, s. 313-320; Э. Доннерт, ор. cit., c. 208.

139 К.С. Чернов, Забытая конституция..., с. 128.

140 Ibidem, c. 43-44, 122. Gdyby, jak utrzymuje autor, Aleksander w pierwszej połowie panowania "obronił swoje prawo do nieograniczonej władzy w walce z arystokracją" (ibidem, c. 122), a rosyjskie elity były gotowe poprzeć reformę, nic nie stałoby na przeszkodzie wprowadzeniu "Gramoty” w 1820 r. Nie byłoby również konieczne utajnienie prac przygotowawczych.

141 Sz. Askenazy, Łukasiński..., t. 1, s. 85.
} 
i dyskrecjonalną władzą reprezentantów monarchy. Cel nadrzędny, czyli wprowadzenie w Cesarstwie Rosyjskim mechanizmów właściwych dla ustroju konstytucyjnego przy zachowaniu samodzierżawia, wyjaśnia wiele kwestii związanych z praktyką polityczną w Królestwie Polskim. Jednocześnie sposób funkcjonowania konstytucyjnych i niekonstytucyjnych organów władzy w Warszawie pozwala zrozumieć, czego oczekiwał Aleksander po wprowadzeniu "Gramoty” w całym państwie. Ponieważ przykład Królestwa uświadomił carowi pewne niebezpieczeństwa związane z reformą, wersja ustawy zasadniczej z 1815 r. została udoskonalona tak, by jeszcze bardziej ograniczyć czynniki ryzyka.

Istotą reformy miało być nie tyle wprowadzenie elementów systemu reprezentacyjnego i praw obywatelskich, co podział Cesarstwa na regiony. Aleksander powracał do idei namiestnictw wielokrotnie, nawet gdy zrezygnował już z „Gramoty”, ponieważ widział w nich najskuteczniejszy środek do osłabienia „służbowej oligarchii”. $Z$ tego samego powodu rosyjski aparat urzędniczy i wojskowy obawiał się federalizacji państwa w równym stopniu, jak ziemiaństwo reformy stosunków agrarnych.

Projekt konstytucyjny, choć obliczony na wzmocnienie władzy cesarskiej i uniezależnienie jej od arystokratycznej elity, nie był całkowicie pozbawiony elementu ideowego. Teza, że rosyjski monarcha pragnął stworzyć system polityczny, który stanowiłby ogniwo „między Wschodem i Zachodem, teokracją i wolnością”, oraz łączył przynależność do szerszej wspólnoty z wystarczającym stopniem niezależności ${ }^{142}$, jest co najmniej godna uwagi. Także wola „uszczęśliwienia poddanych”, deklarowana często przez Aleksandra, nie wydaje się czystą hipokryzją. Wyrażała się ona jednak w sposób skrajnie paternalistyczny, zarówno w odniesieniu do wolności obywatelskich, jak i do samostanowienia narodów. Wolność miała być zawsze „mądrze ograniczona” przez panującego i samoograniczająca się ze strony poddanych. Przyznanie poddanym prawa wybrania na swego reprezentanta „kogo tylko zechcą" nie mieściło się w tych granicach, podobnie jak możliwość oderwania się Królestwa Polskiego czy innych „okrain” od Rosji. Jak trafnie konstatuje Czernow, ,jedną z podstawowych zasad w programie Aleksandra była pełna realizacja idei samodzierżawnej władzy w imię i dla dobra narodu"143.

Realnie rzecz biorąc, wprowadzenie w życie konstytucji z 1820 r. nie było możliwe. Nie upoważnia to jednak do uznania jej tym samym za fantastyczny projekt marzyciela lub schizofrenika. „Ulubiona idea” Aleksandra, jak nazywał w młodości swoje polskie plany, wydawała się równie utopijna, ale na skutek szczególnej koniunktury politycznej przybrała w $1815 \mathrm{r}$. realny kształt w postaci Królestwa Polskiego. Być może car miał nadzieję, że i w tym wypadku pojawią się nowe, sprzyjające okoliczności, które pozwolą mu zrealizować dojrzewający od dawna projekt wzmocnienia swej władzy, restrukturyzacji Imperium i wprowadzenia go

\footnotetext{
142 А. Архангельский, Александр I, Москва 2000, с. 244-245; A. Barańska, op. cit., s. 65-66.

143 К.С. Чернов, Забытая конституция..., с. 11.
} 
na „trzecią drogę” między dotychczasowym systemem a konstytucjonalizmem zachodnim. Popełnił jednak kilka istotnych błędów. Testując nowy model ustrojowy w Królestwie Polskim, nie wziął pod uwagę różnic między kulturą polityczną w Polsce i w Rosji, sięgających znacznie głębiej niż różnice wynikające ze "stopnia rozwoju administracyjnego". Nie odróżniał również wystarczająco dążeń do liberalizacji systemu politycznego od aspiracji niepodległościowych. Wreszcie - i przede wszystkim - nie podjął żadnej poważnej próby uzyskania poparcia politycznego dla planowanej reformy. Stanowiłoby to ogromnie trudne zadanie, ponieważ w Cesarstwie Rosyjskim brakowało środowisk zainteresowanych wprowadzeniem "Gramoty”, zaś niemal wszystkie liczące się siły polityczne były jej przeciwne - brak zaplecza przekreślał jednak z góry szanse na urzeczywistnienie projektu. Aleksander mógł połączyć Królestwo Polskie z Cesarstwem jako kraj autonomiczny i konstytucyjny mimo zdecydowanej opozycji ze strony rosyjskiej elity, ponieważ chodziło o terytorium nowo uzyskane i usytuowane na peryferiach Imperium. Nie mógł jednak zreformować samej Rosji bez przekonania do tego przynajmniej części dotychczasowego establishmentu.

Istnieje opinia, że „Gramota” wyprzedziła o ponad 80 lat reformy wprowadzone przez Mikołaja II po rewolucji 1905 roku $^{144}$. Jak wiadomo, nie ocaliły one Cesarstwa Rosyjskiego przed upadkiem. Jakie mogłyby być hipotetyczne konsekwencje wcielenia w życie zamiarów Aleksandra I? Doraźnie nastąpiłyby prawdopodobnie wzmocnienie autokracji i centralizacja administracji podporządkowanej monarsze. Jednak na dłuższą metę trudno byłoby pogodzić „Gramotę” z samodzierżawiem. Pojawienie się w Cesarstwie sejmów, mimo ich ograniczonych kompetencji i administracyjnej kontroli nad procedurą wyborczą, mogłoby z czasem doprowadzić do tego, że posłowie zasmakują w systemie reprezentacyjnym i zaczną domagać się większego wpływu na sprawy regionu bądź państwa. Z kolei stopniowe obsadzanie organów rządowych w namiestnictwach przez lokalną elitę ziemiańską przyczyniłoby się zapewne do rozwoju identyfikacji regionalnej, a w przypadku terenów etnicznie nierosyjskich - wzrostu poczucia odrębności narodowej i tendencji emancypacyjnych. Zdaniem LeDonne’a nowy system zapewniłby dynastii Romanowów głębsze podstawy władzy niż rozrastająca się biurokracja i olbrzymia $\operatorname{armia}^{145}$, nie wiadomo jednak, czy zreformowane Imperium byłoby wystarczająco atrakcyjne, aby utrzymać swoje nierosyjskie posiadłości bez użycia siły. Historia monarchii habsburskiej skłania, aby na to pytanie odpowiedzieć przecząco.

144 Э. Доннерт, ор. cit., c. 210. W 1905 r. „Gramota” została opublikowana w czasopiśmie „Русский архив” (№ 9, с. 102-128). Jego wydawca, Piotr Iwanowicz Bartieniew, wyraził przy tej okazji pogląd, że dzieło epoki aleksandrowskiej odznaczało się większą przenikliwością i lepiej obejmowało państwowy organizm niż nowo wydany ukaz (z 19 lipca 1905 r.) o Dumie Państwowej, cyt. za: Л.Ф. Писарькова, op. cit., с. 306.

145 Zob. J.P. LeDonne, op. cit., s. 14, 32. 


\section{A Draft of the Russian Constitution of 1820 - A Triumph or Foreboding of the End of the Kingdom of Poland?}

\section{Abstract}

Upon his accession to the throne, Tsar Alexander I began preparing various changes in the administrative and political system of his empire. The apex of all attempts took the form of a draft of the constitution for Russia, worked up in secret in Warsaw in 1818-20 under the control of Count Nikolay Novosiltsev. The tsar approved of the 'Constitutional Charter of the Russian Empire', written in French and Russian, but did not attempt at implementing it.

The draft of 1820 combined the solutions drawn from the Constitution of the Polish Kingdom with the federalist concept (the division of the Russian Empire into ca ten to twelve governorates, introduction of the separate central and regional administrative bodies). At the same time, it confirmed the full sovereignty of the emperor, acknowledged as the only source of power in the state. Tsar Alexander I interpreted key terms and political system ideas in a different way than their West-European authors. The political system envisioned in the 1820 'Constitutional Charter' was not meant to liberalise Russia, but to modernise its administration apparatus and to free the tsar from the clutches of the court and military oligarchy in Saint Petersburg.

The Polish Kingdom served as a testing ground for the planned constitution of Russia. The role of supervisor of this political experiment was played by the tsar's plenipotentiary in Warsaw, Count Nikolay Novosiltsev. According to Tsar Alexander I's concept, the constitution enacted in the Kingdom of Poland in 1815 was not a bilateral agreement but applied only to the citizens. It was protected against "abuse" by punitive measures proportional to its freedoms. An essential element was the simultaneous operation of two structures of power: the legal one (constitutional), and discretionary (non-constitutional). The discretionary power was superior to the legal one and was subordinated directly to Alexander I. It was represented by the governor de facto - Grand Duke Konstantin, and Novosiltsev, who were to control each other. The ultimate goal i.e. the implementation in the Russian Empire some mechanisms of the constitutional system with the preservation of autocracy explains many questions related to the political practice of the Polish Kingdom. On the other hand, the coexistence of constitutional and non-constitutional authorities in Warsaw makes it possible to understand what was expected by Tsar Alexander I after the introduction of the Constitutional Charter in his whole empire.

The tsar did not plan to abolish the autonomy of the Polish Kingdom after the enactment of the Constitution in Russia. He probably considered the creation of two categories of governorates: the native Russian ones and peripheral, established according to the nationality criterion (such as Poland or Finland). The latter would preserve their separate status on the model of Hungary or Lombardy-Venetia within the Habsburg Monarchy. In the case of Poland, the problem was more complicated due to the so-called 'Western Gubernias' (the former lands of the Polish-Lithuanian Commonwealth annexed by the Russian Empire) and their possible incorporation into the Kingdom of Poland.

The draft constitution of 1820 could not be enacted due to the total lack of social and political support. 


\section{Проект российской конституции 1820 года - триумф или предвестник конца царства Польского?}

\section{Аннотация}

С самого начала своего правления Александр I подготавливал различные планы административных и системных реформ. Их коронным достижением был проект конституции для России, разработанный в совершенной секретности в Варшаве в 1818-1820 гг. под руководством Николая Новосильцева. «Уставная грамота», в двух языковых редакциях: французской и русской была одобрена императором, однако он не предпринял попыток ее провозглашения.

Проект от 1820 г. соединял в себе системные решения, позаимствованные из конституции Царства Польского с федералистской концепцией (разделение Российской империи приблизительно на 10-12 наместничеств, введение системы двойных органов власти - центральных и региональных). Одновременно он санкционировал принцип полного суверенитета монарха, признавая его единственным источником власти в государстве. Александр по-другому интерпретировал ключевые термины и идеи из области политики и государственного строя, чем их западноевропейские создатели. Целью системы, спроектированной в Грамоте, не была либерализация России, а модернизация ее администрации и освобождение царя от зависимости от придворной и военной олигархии в Петербурге.

Царство Польское служило Александру I испытательной площадкой для тестирования планируемого государственного строя Империи. Роль руководителя этого политического эксперимента исполнял уполномоченный комиссар царя в Варшаве, Николай Новосильцев. Согласно концепции Александра, конституция, предоставленная Царству в 1815 г. не была двусторонним договором, но обязывала лишь подданных. Репрессивные меры, пропорциональные свободам, должны были предотвратить «злоупотребление» ей. Существенным элементом системы являлось параллельное функционирование двух структур власти: легальной (конституционной) и дискреционной (внеконституционной). Дискреционная власть стояла над легальной и непосредственно подчинялась Александру. Ее представляли наместник de facto - великий князь Константин и Новосильцев, которые должны были контролировать друг друга. Главная цель, коей являлось введение в Российской империи механизмов, характерных для конституционного строя при сохранении самодержавия, разъясняет многие вопросы, связанные с политической практикой в Царстве Польском. С другой стороны, способы функционирования конституционных и неконституционных органов власти в Варшаве позволяют нам понять, чего ожидал Александр после введения Грамоты во всем государстве.

Александр заранее не намеревался упразднить автономию Царства Польского после провозглашения конституции для России. Вероятно, он рассматривал создание двух категорий наместничеств: российских и периферийных, выделенных по национальному признаку (как Польша или Финляндия). У вторых сохранился бы их особый статус по образцу Венгрии или Ломбардии-Венеции в Габсбургской монархии. В случае Польши ситуацию усложнял вопрос т.н. «западных губерний» (бывших территорий Речи Посполитой, присоединенных к Российской империи) и их возможного воссоединения с Царством.

Проект конституционной реформы 1820 г. не мог быть осуществлен из-за отсутствия какой-либо общественной и политической поддержки. 


\section{Bibliografia}

\section{Źródła}

Biblioteka Jagiellońska

rkps 6980 I

Angeberg, comte de [L. Chodźko], Recueil des traités, conventions et actes diplomatiques concernant la Pologne 1762-1862, Paris 1862.

Charte constitutionnelle de l'empire de Russie, Varsovie 1831.

Czartoryski A., Rozważania o dyplomacji, tłum. J.M. Kłoczowski, oprac. M. Kornat, Kraków 2011.

Diariusz Sejmu z r. 1830-1831, wyd. M. Rostworowski, t. 1, Kraków 1907.

"Gazeta Warszawska” (28 III 1818), dodatek do nr 25.

La Charte Constitutionnelle de l'Empire de Russie d'après l'original des archives de St. Pétersbourg, ed. Th. Schiemann, Berlin 1903.

„Le Constitutionnel” (21 XI 1819).

„Le Portfolio ou Collection de documents politiques relatifs à l'histoire contemporaine" 5 (1837).

Le tre costituzioni $(1800,1803,1817)$ delle sette Isole Jonie ed i relativi documenti con l'aggiunta dei due progetti di costituzione del 1802 e 1806 e delle modificazioni e riforme alla costituzione del 1817, Corfu 1849.

Oginski M., Mémoires [...] sur la Pologne et les polonais, depuis 1788 jusquà la fin de 1815, vol. 4, Paris 1827.

Ogiński M., Pamiętniki [...] o Polsce i Polakach. Od roku 1788 aż do końca roku 1815, t. 4, Poznań 1873.

Rzewuska R., Mémoires, ed. G. Caetani Grenier, vol. 2, Rome 1939.

Конституционные проекты в России XVIII - начало XX в., ред. С. Бертолисси, А.Н. Сахаров, Москва 2000.

Конституциионные проекты России 1799-1825, ред. О.Г. Субботин / Constitutional Projects of Russia 1799-1825, ed. O. Subbotin, München 2007.

\section{Opracowania}

Askenazy Sz., Łukasiński, t. 1-2, Warszawa 1929.

Askenazy Sz., Rosja - Polska 1815-1830, Lwów 1907.

Barańska A., Polityka polska Aleksandra I, w: Wolnomularstwo Narodowe. Walerian Łukasiński, red. W. Śliwowska, Warszawa 2014 (Polskie ruchy społeczno-polityczne i życie literackie 1815-1855. Studia i materiały), s. 37-72.

Bartoszewicz K., Utworzenie Królestwa Kongresowego, Kraków 1916.

Bazylow L., Historia Rosji, Wrocław 2006.

Cieszkowski S., Aleksander I a Konstytucja, Warszawa-Lwów 1909.

Frank A., Projet d'une charte constitutionnelle d'Alexandre Ir empereur de Russie, Paris 1859.

Handelsman M., Kryzys r. 1821 w Królestwie Polskim, „Kwartalnik Historyczny” 53 (1939), nr 2, s. 228-247.

Hartley J.M., Is Russia part of Europe? Russian perceptions of Europe in the reign of Alexander I, „Cahiers du monde russe et soviétique” 33 (1992), no. 4, s. 369-385. 
Izdebski H., Ustawa konstytucyjna Królestwa Polskiego z 1815 r., w: Konstytucje Polski. Studia monograficzne z dziejów polskiego konstytucjonalizmu, red. M. Kallas, t. 1, Warszawa 1990, s. $185-232$.

Karnowicz E.P., Wielki książę Konstanty. Zarys biograficzny, Warszawa 1900.

Kornat M., Reforma dyplomacji i legitymizm narodów. Adam Jerzy Czartoryski i jego „Rozważania o dyplomacji”, w: A. Czartoryski, Rozważania o dyplomacji, tłum. J.M. Kłoczowski, oprac. M. Kornat, Kraków 2011, s. 347-602.

Krusenstern A., Rys systemu, postępów i stanu oświecenia publicznego w Rossyi, tłum. K. Jerzmanowski, Warszawa 1838.

Kukiel M., Dzieje Polski porozbiorowe 1795-1921, Paryż 1984.

LeDonne J.P., Regionalism and constitutional reform 1819-1826, „Cahiers du monde russe” 44 (2003), no. 1, s. 5-34.

McConnell A., Alexander I's Hundred Days. The Politics of a Paternalist Reformer, „Slavic Review” 28 (1969), no. 3, s. 373-393.

Pilarczyk P., System polityczny Królestwa Polskiego 1815-1830. Próba modelu, w: System polityczny, prawo, konstytucja i ustrój Królestwa Polskiego 1815-1830, red. L. Mażewski, Radzy$\min 2013$, s. $107-118$.

Pipes R., Rosja carów, tłum. W. Jeżewski, Warszawa 2006.

Rain P., Alexandre Ir. Un tsar idéologue, Paris 1913.

Schiemann Th., Eine Konstitution für Russland vom Jahre 1819, „Historische Zeitschrift” 72 (1894), H. 2, s. 65-70.

Smolka S., Polityka Lubeckiego przed powstaniem listopadowym, wstęp R. Kołodziejczyk, t. 1-2, Warszawa 1983-1984.

Szyndler B., Mikołaj Nowosilcow 1762-1838. Portret carskiego inkwizytora, Warszawa 2004.

Thackeray F.W., Antecedents of Revolution: Alexander I and the Polish Kingdom 1815-1825, New York 1980.

Thackeray F.W., N.N. Novosil'tsov, the Polish Years, „The Polish Review” 28 (1983), no. 1, s. 32-46.

Turek W., Królestwo Polskie $i$ Wielkie Księstwo Finlandii do 1830 r. Ustrojowopolityczne podobieństwa i różnice, w: System polityczny, prawo, konstytucja i ustrój Królestwa Polskiego 1815-1830, red. L. Mażewski, Radzymin 2013, s. 391-408.

Vernadsky G., La Charte constitutionnelle de l'Empire russe de l'an 1820, trad. du russe par S. Oldenburg, Paris 1933.

Zanou K., Beyond „Neo-Hellenic Enlightenment”. Greek intellectuals between the Ionian Islands, Italy and Russia (1800-1830), „CAS Sofia Working Paper Series” 2014, no. 6, s. 1-25.

Архангельский А., Александр I, Москва 2000.

Брикнер А.Г., Панин, граф Никита Петрович, w: Русский биоргафический словарь, ред. А.А. Половцов, т. 13, Санкт-Петербург 1902, с. 205-211.

Доннерт Э., Либеральный конституционализм и конституциионые проекты времени Александра І для Финляндии, Польши и России, w: Славянские народь. Общность истории и культуры, ред. Б.В. Носов, Москва 2000, с. 186-214.

Кодан С.В., Владимирова Г.Е., Политико-идеологические и организационно-правовые предпосылки создания Основных государственных законов Российской империи (XVIII - первая четверть XIX вв.), „Genesis. Исторические исследования” 2 (2013), № 4, c. 134-171, https://nbpublish.com/library_read_article.php?id=745.

Майков П.М., Розенкампф Густав Андреевич, w: Русский биоргабический словарь, ред. А.А. Половцов, т. 16, Санкт-Петербург 1913, с. 365-371.

Мироненко С.В., Самодержавие и ребормы. Политическая борьба в России в начале ХІХ века, Москва 1989. 
Мироненко С.В., Страниць тайной истории самодержавия. Политическая история первой половины ХІХ столетия, Москва 1990.

Писарькова Л.Ф., Государственное управление России в первой четверти ХІХ века. Замысльи, проекты, воплощение, Москва 2014.

Пыпин А.Н., Общественное движение при Александре I, изд. 5, Петроград 1918.

Сахаров А.Н., Конституционные проекты и иивилизационные судьбы России, w: Конституционные проекты в России XVIII - начало XX в., ред. С. Бертолисси, А.Н. Сахаров, Москва 2000, с. 9-78.

Станиславская А.М., Россия и Греция в конце XVIII - начале XIX вв. Полиӥика России в Ионической республике 1798-1807, Москва 1976.

Филатова Н.М., Русское общество и Королевство Польское в 1815-1830 г2., w: Польша и Россия в первой трети ХІХ века. Из истории автономного Королевства Польского 1815-1830, Москва 2010, с. 469-518.

Чернов К.С., Забытая конституиия. „Государственная Уставная Грамота Российской Империи”, Москва 2007.

Чернов К.С., «Правительственньй конституичонализм» первой четверти ХІХ в. (на примере „Государственной уставной грамоты Российской империи”), „Труды Исторического факультета Санкт-Петербургского университета" 3 (2012), № 11, c. $172-180$.

Шильдер Н.К., Император Александр Первый. Его жизнь и иарствование, т. 1-4, Санкт-Петербург 1897-1898.

Шилов Д.Н., Государственные деятели Российской империи. Главы высших иентральных учреждений 1802-1917. Биобиблиограбический справочник, Санкт-Петербург 2002.

Anna Barańska, dr hab., prof. Katolickiego Uniwersytetu Lubelskiego, zatrudniona w Instytucie Historii KUL. Specjalizuje się w badaniach nad historią XIX w.: Królestwo Polskie 1815-1830, powstanie listopadowe, Rosja za Aleksandra I, kobiety polskie w okresie zaborów, historia Kościoła katolickiego na ziemiach polskich pod zaborami, dyplomacja Stolicy Apostolskiej, stosunki między Kościołem a Państwem w Europie w XIX w. (anbar@kul.pl).

Anna Barańska, dr. hab., assistant prof. of the John Paul II Catholic University of Lublin, employee of the Institute of History of CUL. She specialises in the history of the $19^{\text {th }}$ century: Kingdom of Poland 1815-30, the November Uprising, Russia under Alexander I, Polish women of the partition period, history of the Catholic Church in the Polish lands under the partitions, diplomacy of the Holy See, the Church-State relations in $19^{\text {th }}$-century Europe (anbar@kul.pl). 